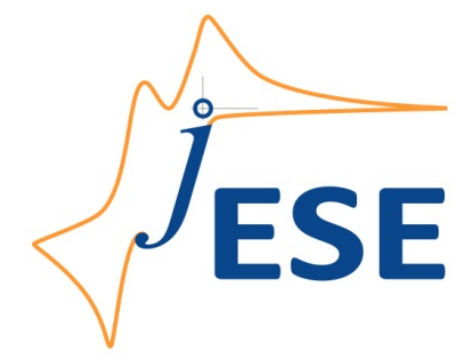

Open Access : : ISSN 1847-9286

www.jESE-online.org

Review

\title{
On the stability of perchlorate ions against reductive attacks in electrochemical systems and in the environment
}

\author{
MÁRIA UJVÁRI ${ }^{\varpi}$ and GYŐZŐ G. LÁNG
}

Eötvös Loránd University, Institute of Chemistry, Department of Physical Chemistry, Laboratory of Electrochemistry and Electroanalytical Chemistry, PO Box 32, Budapest 112, H-1518, Hungary

marcsi@chem.elte.hu

Received: June 16, 2011; Published: August 20, 2011

\begin{abstract}
The problems related to the electrochemical/electrocatalytic stability of perchlorate ions are reviewed in the light of recent experimental results. The electrocatalytic, catalytic, and electrochemical reduction processes are presented and the links between them are outlined. Some possible mechanisms of the complicated reduction processes are discussed. Various methods for the detection of reduction process are presented, e.g. voltammetry, impedance spectroscopy, and radiotracer methods. Environmental aspects and some methods for perchlorate removal and wastewater treatment are briefly summarized.
\end{abstract}

\section{Keywords}

Perchlorate ions; Environmental contamination; Waste water treatment; Electrocatalytic reduction; Reduction mechanism; Noble metals; Corrosion

\section{Introduction}

Based on the thermodynamic data presented in Table 1, $\mathrm{ClO}_{4}^{-}$should be instable against reductive attacks in acidic medium in a wide potential range. In contrast, in the electrochemical literature $\mathrm{ClO}_{4}^{-}$are often considered to be very stable anions.

Therefore, perchlorate containing solutions are widely used as supporting electrolytes in electrochemical studies with various electrodes. Among these investigations reports concerning dissolution, deposition, and corrosion of metals can also be found.

In such studies, it is tacitly assumed that the reduction of the $\mathrm{ClO}_{4}^{-}$is not taking place under the actual experimental conditions. However, evidence for the occurrence of the reduction process has been reported for Rh [1-5], Pt [6-9], WC [10], Al [11], Ti [12], Ir [13], Ru [14], Re [15], Tc [16], 
and Sn [17] electrodes. A survey of the literature can be found in recent reviews [18-21]. These observations prompt us to keep in mind the possibility of the occurrence of the reduction process at any electrode used in an aqueous acid medium containing perchlorate ions.

Table 1. Standard potential values of reaction steps potentially involved in the reduction of $\mathrm{ClO}_{4}^{-}$*

\begin{tabular}{lc}
\hline Reaction & $E^{0} / \mathrm{V}$ \\
\hline $\mathrm{ClO}_{2}+\mathrm{e}=\mathrm{ClO}_{2}^{-}$ & 0.93 \\
$\mathrm{ClO}_{3}^{-}+2 \mathrm{H}^{+}+\mathrm{e}=\mathrm{ClO}_{2}+\mathrm{H}_{2} \mathrm{O}$ & 1.15 \\
$\mathrm{ClO}_{4}^{-}+2 \mathrm{H}^{+}+2 \mathrm{e}=\mathrm{ClO}_{3}^{-}+\mathrm{H}_{2} \mathrm{O}$ & 1.19 \\
$\mathrm{ClO}_{2}+\mathrm{H}^{+}+\mathrm{e}=\mathrm{HClO}_{2}$ & 1.27 \\
$\mathrm{HClO}_{+} \mathrm{H}^{+}+2 \mathrm{e}=\mathrm{Cl}^{-}+\mathrm{H}_{2} \mathrm{O}$ & 1.50 \\
$\mathrm{HClO}_{2}+2 \mathrm{H}^{+}+2 \mathrm{e}=\mathrm{HClO}+\mathrm{H}_{2} \mathrm{O}$ & 1.64 \\
$*$ Selected constants. Charlot, G.; Collumeau, A.; Marchon, M.J.C. Oxidation-Reduction Potentials \\
of Inorganic Substances in Aqueous Solution, Butterworths, London, 1971.
\end{tabular}

Besides the significance of perchlorate reduction for the fundamental electrochemistry today, a very practical reason, the so-called perchlorate contamination challenge, came into foreground directing the attention towards the reductive elimination of perchlorate ions.

Perchlorates are used as an oxidizer component and primary ingredient in solid propellants for rockets, missiles, and fireworks. Therefore, dissolved ammonium, potassium, magnesium, or sodium salts are present as contaminants in groundwater and surface waters originating from improper disposal of the solid propellants and from the wastewaters of the manufacturing plants. As the sorption or natural chemical reduction of perchlorate in the environment is not significant, perchlorates are exceedingly mobile in aqueous systems and can persist for many decades under typical ground and surface water conditions. According to different reports [22-27], a large number of water sources in the United States have been contaminated with perchlorate. However, the perchlorate problem is not located to the US only. This type of contamination constitutes a major problem in China [28-30] and many other countries in the world [31-33]. For example, in Israel, an ammonium-perchlorate manufacturing plant that had been disposing untreated wastewater in four unlined ponds for 25 years caused extensive perchlorate contamination in the underlying aquifer. The perchlorate migration in the deep vadose zone has been found very low under natural recharge conditions in the semiarid region [34].

One of the main health hazards is connected with the very fact that perchlorate interferes with iodide uptake in the thyroid gland $[35,36]$. In large doses, it has been linked to anemia and fetal brain damage [30,35].

Several technologies have been studied for the treatment of perchlorate contaminated water, such as chemical precipitation and reduction, bioreduction, anion exchanges, electroreduction, membrane filtration, electrodialysis, and photocatalytic reduction. Even though some of these have been adopted for drinking water treatment, the optimization of cost, selectivity, and effective treatment is still a serious problem [37-39]. The electrochemical treatment method is one of the methods [20] considered applicable for solving the perchlorate contamination [24-26]. The elaboration of a treatment technology with dissolved complexes is significantly hindered by its high cost and significant difficulties with the regeneration or treatment of their end products. Some recent results in waste water treatment are presented below. 
The electrochemical and electrophotocatalytic reduction of the perchlorate ion to the chloride ion were assessed at laboratory scale [40]. The study was carried out in two-chambered batch reactor systems in which the cathodic and anodic compartments were separated by an ion

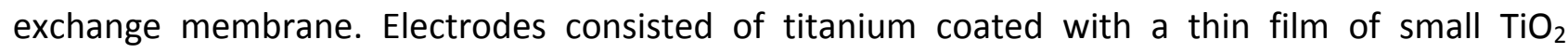
particles. Test water systems were buffered to an acid $\mathrm{pH}$ and background electrolyte was added. For photolytic systems, concentrations ranged from $5 \times 10^{-2} \mathrm{~mol} \mathrm{dm}^{-3}$ to $5 \times 10^{-7} \mathrm{~mol} \mathrm{dm}^{-3}$. Reduction initially proceeded rapidly but slowed with time. The percentage of perchlorate electrochemically reduced after $2 \mathrm{~h}$ was found to range from less than $1 \%$ at the highest concentration to $30-35 \%$ at lower concentrations. The extent of photocatalytic reduction at high perchlorate concentrations was approximately five times greater than the extent of electrochemical reduction at the same concentrations. An additional fourfold improvement in reduction percentage was observed when the electrode was doped with vanadium. A mathematical model suggested that the limiting factor in perchlorate reduction was the competition among anions for active sites on the electrode surface.

An electrically controlled anion-exchange process has been proposed to remove perchlorate ions from the industrial wastewaters [41]. A nanostructured conducting copolymer poly(anilineco-o-aminophenol) (PANOA) was electrochemically synthesized on a glassy carbon (GC) electrode and its redox and anion exchange properties for perchlorate removal were investigated by cyclic voltammetry, FTIR, and X-ray photoelectron spectroscopy (XPS). FTIR spectra demonstrated that $\mathrm{ClO}_{4}^{-}$were immobilized in the copolymer film after its oxidation in a solution containing $\mathrm{NaCl}$ and $\mathrm{NaClO}_{4}$. The result of XPS spectra showed that the copolymer films oxidized in a solution containing $0.10 \mathrm{~mol} \mathrm{dm}^{-3} \mathrm{NaCl}$ and $0.010 \mathrm{~mol} \mathrm{dm}{ }^{-3} \mathrm{NaClO}_{4}$ at $\mathrm{pH} 5.7$ and 9.0 had $\mathrm{ClO}_{4}^{-} / \mathrm{Cl}^{-}$molar ratio of 0.53 and 0.31 , respectively, which were significantly higher than the 0.10 ratio in the tested aqueous solution.

New, potentially green, and efficient synthetic routes for the remediation and/or re-use of perchlorate-based energetic materials have been suggested in two other studies [42,43]. Four simple organic imidazolium- and phosphonium-based perchlorate salts/ionic liquids have been synthesized by simple, inexpensive, and nonhazardous methods, using ammonium perchlorate as the perchlorate source. By appropriate choice of the cation, perchlorate can be incorporated into an ionic liquid, which serves as its own electrolyte for the electrochemical reduction of the perchlorate anion. The electrochemical degradation of the hazardous perchlorate ion and its conversion to harmless chloride during electrolysis was studied using $\mathrm{IR}$ and $\mathrm{Cl}-35 \mathrm{NMR}$ spectroscopies.

Bioelectrochemical systems (BESs) including microbial fuel cells (MFCs) and microbial electrolysis cells (MECs) integrate three important wastewater treatment options, namely, biological treatment, electrolytic dissolution, and electrochemical oxidation/reduction and are regarded as new sustainable and effective strategies for wastewater processing. An up-to-date review is provided on recent research and development in BESs-based recalcitrant wastes treatment [44]. Recently, the reduction of perchlorate in the cathode compartment of a BES has been described [45]. The authors were able to isolate one of the organisms (Dechlorospirillum strain VDY) responsible for the perchlorate reduction. At a potential of $-500 \mathrm{mV} \mathrm{vs} . \mathrm{Ag} / \mathrm{AgCl}$ reference electrode, the organism was capable of reducing perchlorate without the addition of a redox mediator. The results of these studies demonstrate that biological perchlorate remediation can be facilitated through the use of an electrode as the primary electron donor, and that continuous treatment in such a system approaches current industry standards. An MFC with a 
denitrifying biocathode for perchlorate reduction has been investigated to identify putative biocathode-utilizing perchlorate-reducing bacteria (PCRB), which can utilize a cathode as an electron donor, and this process can be harnessed to treat perchlorate while producing usable electrical power [46].

Perchlorate reduction has been observed with certain transition metal complexes and metal chelates, but the reactions are generally sluggish. A swift-oxo transfer reaction of perchlorate by rhenium oxazalin and thiazoline complexes has been reported quite recently $[47,48]$. The characteristic features of the new family of these molecular oxotransferases are their rapid kinetics and their ability in catalysing the very difficult reduction of perchlorate by atom transfer.

New (Re-Pd) bimetallic heterogeneous catalysts [49,50] for the reduction of perchlorate in water with dihydrogen have been prepared in two ways: (1) by impregnating $5 \mathrm{wt} \% \mathrm{Pd}$ on activated carbon powder with one of the complexes trans-[ReO $\left.\mathrm{R}_{2}(\mathrm{py}-\mathrm{X})(4)\right](+)(p y-X=4$-substituted pyridine; $\mathrm{X}=\mathrm{H}, \mathrm{Me}, \mathrm{OMe}, \mathrm{NMe}_{2}$ ) or (2) by adsorbing perrhenate onto the $\mathrm{Pd} / \mathrm{C}$ powder in the presence of the pyridine ligand under a hydrogen atmosphere. Both sets of catalysts are highly active at $\mathrm{pH}$ 2.7-3.0 ( $\mathrm{HCl})$, with observed rates increasing with varying $X$ in the order $\mathrm{H}<\mathrm{Me}<\mathrm{OMe}<\mathrm{NMe}_{2}$, which supports a rate-determining oxygen atom transfer reaction involving the $\operatorname{Re}(\mathrm{V})$ centers [51].

Granular activated carbon (GAC) coated with iron compounds (ICS) [52] or cetyltrimethyl ammonium bromide (CTAB) [53] were synthesized to remove perchlorate from water via adsorption. Laboratory-scale batch experiments were performed to study the factors affecting the perchlorate adsorption. In case of ICS/GAC, $97 \%$ of the perchlorate ions were removed within $10 \mathrm{~h}$ at $90{ }^{\circ} \mathrm{C}$. The experimental results also showed that $\mathrm{FeOHSO}_{4}$ and $\mathrm{Fe}_{2} \mathrm{O}_{3}$ nanoparticles have the function of perchlorate adsorption and play important roles in $\mathrm{ClO}_{4}^{-}$removal. In case of CTAB/GAC, the optimal adsorption occurred at $\mathrm{pH} 2-3$, and the mechanisms were associated with surface complexation, electrostatic interaction, and ion exchange.

Studies in heterogeneous reaction of dissolved perchlorate ions with metals open a new possible pathway for new approaches in the technology. In recent years, the possible application of iron has been investigated [54], including the rate and extent of perchlorate reduction on several types of iron metal in batch and column reactors. Mass balances performed on the batch experiments indicate that perchlorate is initially sorbed to the iron surface, which is followed by a reduction to chloride. Perchlorate removal was proportional to the iron dosage in the batch reactors, with up to $66 \%$ removal in the period of $336 \mathrm{~h}$ in the highest dosage system $\left(1.25 \mathrm{~g} \mathrm{ml}^{-1}\right)$. The most significant perchlorate removal occurred in solutions with slightly acidic or near-neutral initial $\mathrm{pH}$ values. Elevated soluble chloride concentrations significantly inhibited perchlorate reduction, and lower removal rates were observed for iron samples with higher amounts of background chloride contamination. The reactive iron phase is neither pure zero-valent iron nor the mixed oxide alone. A mixed valence iron hydr(oxide) coating or a sorbed $\mathrm{Fe}^{2+}$ surface complex represent the most likely sites for the reaction. The use of zero-valent iron for treating wastewaters containing RDX (cyclotrimethylene trinitramine) and perchlorate from an army ammunition plant (AAP) in the USA at elevated temperatures and moderately elevated temperature with chemical addition was evaluated in batch and column experiments [55].

The interaction of a metal with dissolved perchlorate ions should be considered as a corrosion process, i.e. the overall transformation is composed of at least two or three reactions:

$$
\mathrm{Me}+2 \mathrm{H}^{+} \rightarrow \mathrm{Me}^{2+}+\mathrm{H}_{2}
$$




$$
4 \mathrm{Me}+\mathrm{ClO}_{4}^{-}+8 \mathrm{H}^{+} \rightarrow \mathrm{Cl}^{-}+4 \mathrm{Me}^{2+}+4 \mathrm{H}_{2} \mathrm{O}
$$

From the electrochemical point of view, this formulation involves three charge transfer processes:

$$
\begin{aligned}
& \mathrm{Me} \rightarrow \mathrm{Me}^{2+}+2 \mathrm{e}^{-} \\
& \mathrm{H}^{+}+\mathrm{e}^{-} \rightarrow \frac{1}{2} \mathrm{H}_{2} \\
& \mathrm{ClO}_{4}^{-}+8 \mathrm{H}^{+}+8 \mathrm{e}^{-} \rightarrow \mathrm{Cl}^{-}+4 \mathrm{H}_{2} \mathrm{O}
\end{aligned}
$$

This last step should be a very complex one composed of several elementary steps. The equations given above involve the coupling of the anodic dissolution of the metal with two cathodic processes: discharge of protons and reduction of $\mathrm{ClO}_{4}^{-}$.

In principle, the reduction of $\mathrm{ClO}_{4}^{-}$could occur through a "catalytic mechanism" via the interaction with hydrogen atoms adsorbed on the metal surface.

It follows from these considerations that the problem of perchlorate reduction constitutes an intersection of several branches of sciences: electrochemistry (anodic dissolution of metals, discharge of protons); corrosion science (coupling of cathodic and anodic processes); catalysis (electrocatalysis); and heterogeneous chemical processes. In this paper, we present the historical background of the relevant topics in the light of recent developments and some new results obtained from the studies of direct interaction of perchlorate ions with various metals.

\section{Heterogeneous catalytic/electrocatalytic aspects of perchlorate reduction}

In 1971, Butula and Butula [56] found that $\mathrm{HClO}_{4}$ could be reduced if $\mathrm{Pd} / \mathrm{BaSO}_{4}$ and $\mathrm{Rh} / \mathrm{C}$ catalyst was used in acetic acid at $60^{\circ} \mathrm{C}$. In the same decade, the hydrogenation of perchlorate ions was studied at different temperatures and different perchlorate and hydrogen ion concentrations [20].

It was demonstrated that $\mathrm{ClO}_{4}^{-}$dissolved in acidic aqueous solutions could be reduced to $\mathrm{Cl}^{-}$by molecular hydrogen in the presence of powdered platinum black catalyst [9]. Considering the link between the liquid (aqueous) phase heterogeneous catalytic hydrogenation and electrocatalytic reduction, it was easy to draw the conclusion that electrocatalytic/electrochemical reduction of $\mathrm{ClO}_{4}^{-}$could be performed at electrodes prepared from materials identical to the material of catalyst powders used in the catalytic hydrogenation [57].

Electrodes with "catalytic" properties, such as Pt, Rh, Pd, Ir, and Ru, have been in the focus of interest. There was, and perhaps still is, a general belief in the literature that perfect voltamograms reflecting $\mathrm{H}$ adsorption on these electrodes can be obtained in $\mathrm{HClO}_{4}$ solution. Although in addition to $\mathrm{Pt}$ and $\mathrm{Rh}$ electrodes $\mathrm{ClO}_{4}^{-}$reduction on $\mathrm{Ir}$ [13] and $\mathrm{Ru}$ [14] conveyed the warning to be cautious with noble metal electrodes when using $\mathrm{HClO}_{4}$ supporting electrolyte, most electrochemists in their various studies [58-60] carried out in the presence of $\mathrm{HClO}_{4}$ supporting electrolyte ignored the possible complications that should be ascribed to the occurrence of a reduction process involving $\mathrm{ClO}_{4}^{-}$.

In 1990, it became evident that the contradictory results obtained during previous decades could be explained if it was assumed that the reduction of the $\mathrm{ClO}_{4}^{-}$was characteristic not only for the rhodized surfaces, but also for smooth polycrystalline surfaces and well-defined crystal faces 
[3-5]. By this approach, almost all difficulties encountered in the interpretation of various phenomena could be eliminated during the last few years.

Thus far, the majority of the published experimental results were obtained by using combined voltammetric, amperometric, EQCM, impinging jet, and radiotracer methods $[1,3,4,13,19,20,61$ 65].

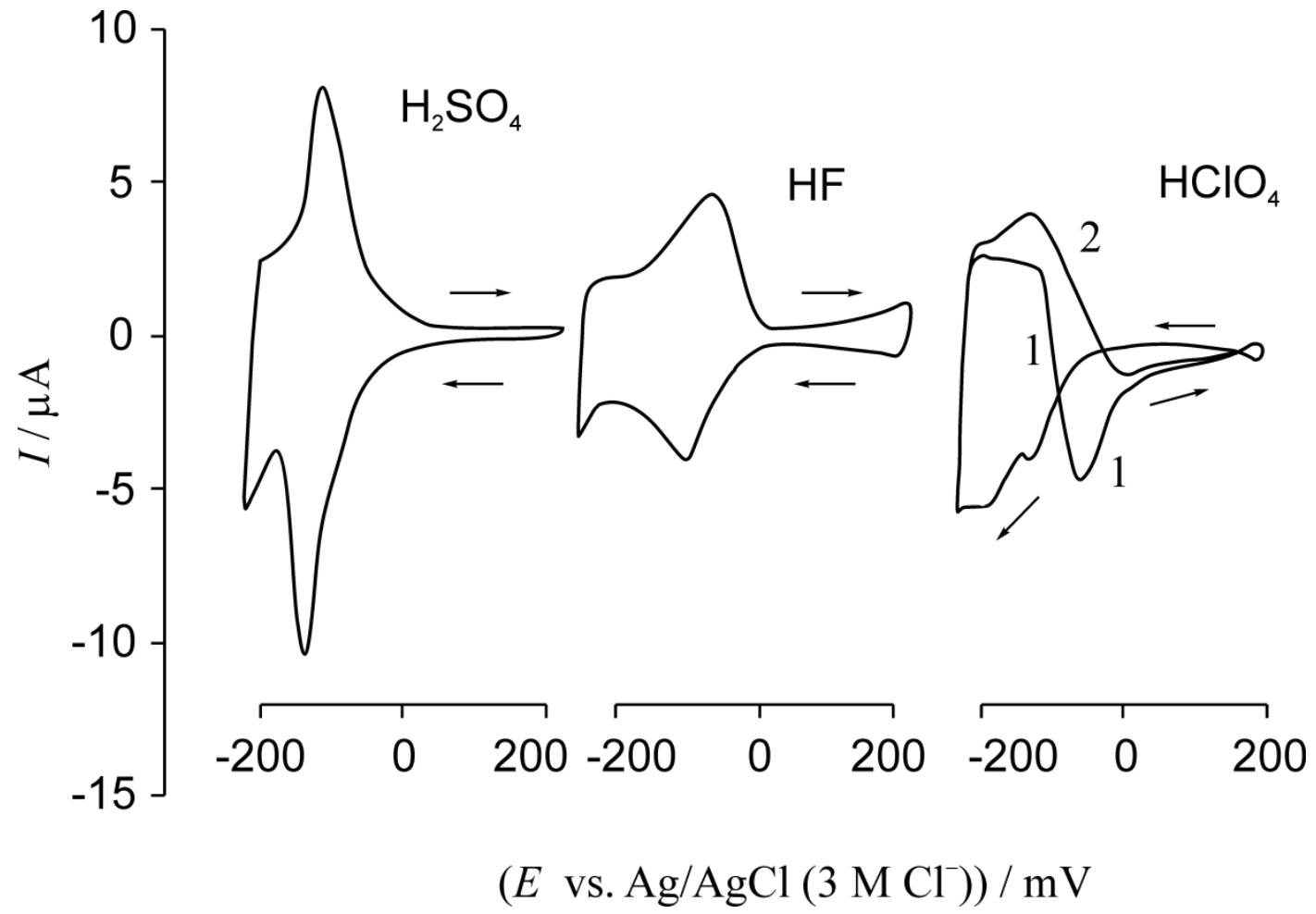

Figure 1. Voltamograms obtained for rhodized electrodes in different electrolytes; acid concentration $1 \mathrm{~mol} \mathrm{dm}^{-3}$, sweep rate $=5 \mathrm{mV} \mathrm{s}^{-1}$. Adapted from [61].

The distortion of voltammetric curves in the presence of $\mathrm{ClO}_{4}^{-}$is the firm evidence of the occurrence of the reduction process. Figure 1 shows the voltammetric curves obtained in $1 \mathrm{~mol} \mathrm{dm}^{-3} \mathrm{H}_{2} \mathrm{SO}_{4}, \mathrm{HF}$ and $\mathrm{HClO}_{4}$ supporting electrolytes using rhodized electrodes [61]. In the case of $\mathrm{H}_{2} \mathrm{SO}_{4}$ and $\mathrm{HF}$, despite some differences between them, the voltammetric curves behave "normally" as expected. In contrast, the voltammetric curve obtained in the presence of perchloric acid is distorted. The negative peak in the course of the positive sweep clearly indicates the occurrence of a cathodic process, namely, the reduction of perchlorate ions. Similar voltammetric curves were obtained with single- and polycrystalline smooth $\mathrm{Rh}[3,4]$ and platinized Pt [8] surfaces. Electrochemical behavior of $\operatorname{Ir}(100)$ in perchloric acid solutions has been characterized elsewhere [66]. The asymmetry of the cyclic voltammograms recorded in the double-layer region could be attributed to a slow reduction process, e.g. the reduction of perchlorate ions.

The characteristic features common to these systems are as follows:

(a) Nowadays, there is a general agreement that the rate of reduction of $\mathrm{ClO}_{4}^{-}$at noble metal and catalytic electrodes should be very low at both ends of the potential scale; consequently the I vs. E curve should go through a minimum.

(b) The reduction process occurs almost exclusively during the positive sweep of the cyclic voltammogram.

(c) Generally, no reaction can be observed on the negative sweeps, but the shape, height, and position of the corresponding hydrogen peak differ significantly from those expected. 
(d) The distortion of the anodic peak gradually disappears during subsequent cycles, but the anodic and cathodic peaks remain asymmetric.

(e) The only reduction product found in the solution was $\mathrm{Cl}^{-}$.

(f) The very rapid decrease in the electrocatalytic activity with respect to $\mathrm{ClO}_{4}^{-}$- reduction can be explained by self-inhibition, namely, by the inhibiting action of $\mathrm{Cl}^{-}$formed during reduction and adsorbed on the electrode surface. The higher the $\mathrm{Cl}^{-}$concentration, the more pronounced is its inhibitive effect.

(g) The desorption of $\mathrm{Cl}^{-}$from the metal surface is a very slow process. For instance, no measurable desorption of $\mathrm{Cl}^{-}$were detected until several minutes after switching the electrolyte solution from $1 \mathrm{~mol} \mathrm{dm}^{-3} \mathrm{HF}+10^{-4} \mathrm{~mol} \mathrm{dm}^{-3} \mathrm{HCl}$ to $1 \mathrm{~mol} \mathrm{dm} \mathrm{m}^{-3} \mathrm{HF}[62,67]$.

According to the results presented in the literature, the rate of electrocatalytic reduction of perchlorates on $\mathrm{Rh}$ is relatively high. The reduction process leading to the formation of $\mathrm{Cl}^{-}$should be a very complicated reaction as eight electrons are involved in the overall process. It is difficult to believe that it can be performed without the formation of any stable intermediates or products of side-reactions. Analogous to the reduction of perchlorate in homogeneous solution, the reduction of perchlorate at an electrode (or any surface) must involve oxygen atom transfer. Therefore, the controversy regarding the mechanism of the reduction of $\mathrm{ClO}_{4}^{-}$on rhodium is not surprising. According to the "classical" view, the rate-determining step in the electrocatalytic process can be described as a reaction of adsorbed $\mathrm{ClO}_{4}^{-}$species with adsorbed $\mathrm{H}$ atoms $[1,13,19,61,62,67]$. In contrast, the reduction process can be considered as a slow decomposition of $\mathrm{ClO}_{4}^{-}$species on the surface followed by fast reduction steps [63]. The latter approach is based on the view that the reduction rate attains a measurable level at potentials where the surface concentration of $\mathrm{H}$ is very low; consequently, it is unlikely that it can play any role. Thus, it should be assumed that the rate-determining step is the decomposition of adsorbed $\mathrm{ClO}_{4}^{-}$with the participation of a free adsorption site in its neighborhood.

In accordance with the above considerations, three fundamental types of possible mechanisms are distinguished for the electrocatalytic reduction of $\mathrm{ClO}_{4}^{-}[13,20,21,61-63,65,67]$, namely the mechanism (A) involving protons and/or adsorbed hydrogen, the serial mechanism (B) and the mechanism (C) involving free-metal sites.

Mechanism (A) can follow two alternative paths:

$$
\begin{aligned}
& \mathrm{ClO}_{4}^{-}(\text {sol }) \rightleftharpoons \mathrm{ClO}_{4}^{-}(\text {ads }) \\
& \mathrm{H}^{+}(\text {sol })+\mathrm{e}^{-} \rightleftharpoons \mathrm{H}(\text { ads }) \\
& \mathrm{ClO}_{4}^{-}(\text {ads })+\mathrm{H}(\text { ads }) \rightarrow \text { intermediates } \rightarrow \mathrm{Cl}^{-}(\text {ads }) \rightarrow \mathrm{Cl}^{-}(\text {sol })
\end{aligned}
$$

or

$$
\begin{aligned}
& \mathrm{ClO}_{4}^{-}(\text {sol }) \rightleftharpoons \mathrm{ClO}_{4}^{-} \text {(ads) } \\
& \mathrm{ClO}_{4}^{-}(\text {ads })+\mathrm{H}^{+}+\mathrm{e}^{-} \rightarrow \text { intermediates } \rightarrow \mathrm{Cl}^{-}(\text {ads }) \\
& \mathrm{Cl}^{-}(\text {ads }) \rightleftharpoons \mathrm{Cl}^{-}(\text {sol })
\end{aligned}
$$

Mechanism (B):

$$
\mathrm{ClO}_{4}^{-} \rightleftharpoons \mathrm{ClO}_{4}^{-}(\text {ads })
$$




$$
\begin{aligned}
& \left.\mathrm{ClO}_{4}^{-}(\text {ads }) \rightarrow \mathrm{ClO}_{3}^{-} \text {(ads }\right)+\mathrm{O}(\text { ads }) \\
& \mathrm{O}(\text { ads })+2 \mathrm{H}^{+}+2 \mathrm{e}^{-} \rightarrow \mathrm{H}_{2} \mathrm{O} \\
& \left.\mathrm{ClO}_{3}^{-}(\text {ads }) \rightarrow \mathrm{ClO}_{2}^{-} \text {(ads }\right)+\mathrm{O}(\text { ads }) \\
& \mathrm{O}(\text { ads })+2 \mathrm{H}^{+}+2 \mathrm{e}^{-} \rightarrow \mathrm{H}_{2} \mathrm{O} \\
& \left.\mathrm{ClO}_{2}^{-}(\text {ads }) \rightarrow \mathrm{ClO}^{-} \text {(ads }\right)+\mathrm{O}(\text { ads }) \\
& \mathrm{O}(\text { ads })+2 \mathrm{H}^{+}+2 \mathrm{e}^{-} \rightarrow \mathrm{H}_{2} \mathrm{O} \\
& \mathrm{ClO}(\text { ads }) \rightarrow \mathrm{Cl}^{-}(\text {ads })+\mathrm{O}(\text { ads }) \\
& \mathrm{O}(\text { ads })+2 \mathrm{H}^{+}+2 \mathrm{e}^{-} \rightarrow \mathrm{H}_{2} \mathrm{O}
\end{aligned}
$$

where "(ads)" denotes that the species is adsorbed, while "(sol)" refers to components in the solution phase. According to this scheme, the whole process starting from perchlorate ion occurs on the surface and the role of desorption of intermediates can be neglected, i.e. their desorption rate is very low compared with the rate of the chemical transformation.

Mechanism (C):

According to this mechanism, it should be assumed that the rate-determining step is the decomposition of adsorbed perchlorate ion if a free "active" site $(\otimes)$ is in its neighborhood. This assumption is the same as that made in [64] in connection with the reduction of $\mathrm{N}_{2} \mathrm{O}$.

The decomposition reaction can be written as:

$$
\otimes+\mathrm{ClO}_{4}^{-} \rightarrow \text { intermediates } \rightarrow \mathrm{Cl}^{-}
$$

On the other hand, it can be assumed that the surface concentration of active sites is determined by the following reactions:

$$
\otimes+\mathrm{H}_{2} \mathrm{O} \rightleftharpoons \otimes-\mathrm{OH}+\mathrm{H}^{+}+\mathrm{e}^{-}
$$

or

$$
\otimes+\mathrm{OH}^{-} \rightleftharpoons \otimes-\mathrm{OH}+\mathrm{e}^{-}
$$

In this case, the potential dependence of the surface concentration of free active sites plays an important role.

In the reaction schemes proposed in the literature, the adsorption of perchlorate ion is an elementary step in the overall reduction. The decomposition of the adsorbed perchlorate ion is assumed to be slow; however, there are only speculations about the rates of the subsequent steps. For instance, in the mechanism (B) all decomposition steps are assumed to be slow, but no rigorous investigation of this problem has yet been performed.

The electrochemical reduction of perchlorate ions on rhodium and ruthenium was investigated in a series of experiments (voltammetry, chronoamperometry, impedance spectroscopy) performed at different electrode potentials $(E)$ and different temperatures $(T)$.

Figure 2 shows cyclic voltammograms obtained for a Rh rotating disc electrode in contact with a $3 \mathrm{~mol} \mathrm{dm}{ }^{3} \mathrm{HClO}_{4}$ solution [67]. 


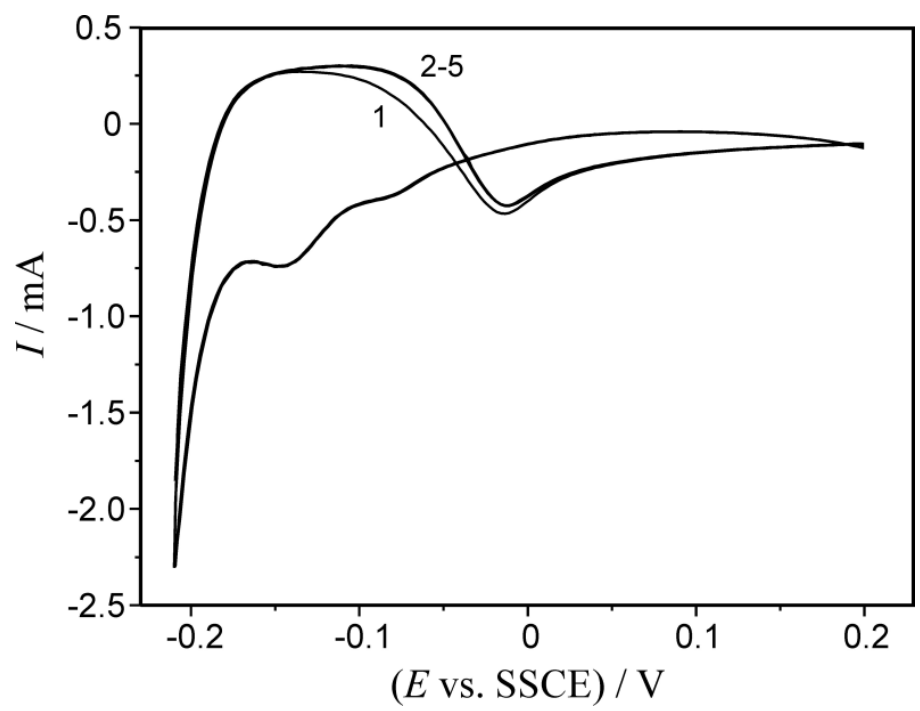

Figure 2. Cyclic voltammograms obtained for a Rh rotating disc electrode in contact with a $3 \mathrm{~mol} \mathrm{dm}^{-3}$ $\mathrm{HClO}_{4}$ solution (geometric surface area of the electrode: $\mathrm{A}=0.196 \mathrm{~cm}^{2}$, rotation rate: $\omega_{r}=950 \mathrm{rpm}$, temperature: $\mathrm{T}=25.0^{\circ} \mathrm{C}$ ). Adapted from [67]. (SSCE: sodium saturated calomel electrode)

There is a distinct difference between the curves recorded at stagnant electrodes and the curves obtained with the RDE. In case of stationary electrodes, the distortion of the anodic peak gradually disappears during subsequent potential cycles, i.e. the negative current during the positive sweep is continuously decreasing over the consecutive scans. In contrast, in case of rotating disc electrodes, the shape of the voltammogram does not change after the second or third cycle, and a negative current can be always observed during the positive sweep. It means that the desorption rate of $\mathrm{Cl}^{-}$generated during the reduction process is significantly influenced by the hydrodynamic conditions, probably through desorption/diffusion coupling. This conception is supported by the results of chronoamperometric measurements carried out at different temperatures. The curves obtained at $T=45^{\circ} \mathrm{C}$ are presented in Figure 3 [67].

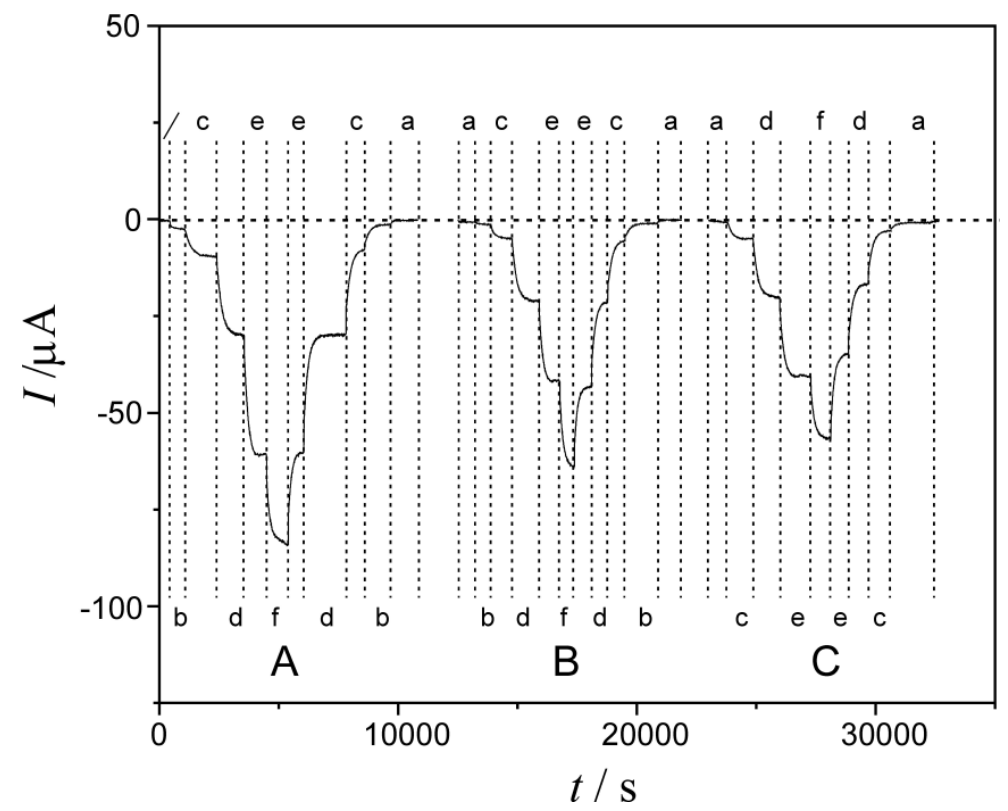

Figure 3. Chronoamperometric measurements. The current (I) as a function of time (t) at constant electrode potentials and at different electrode rotation rates. Electrode potentials:

A: $0.01 \mathrm{~V}$ vs. SSCE; B: $0.06 \mathrm{~V}$ vs. SSCE; C: $0.11 \mathrm{~V}$ vs. SSCE. Rotation rates $\left(\omega_{r}\right)$ :

a: 0 rpm; b: 500 rpm; c: 1000 rpm; d: 2000 rpm; e: 3000 rpm; f: 4000 rpm.

(geometric surface area of the electrode: $\mathrm{A}=0.196 \mathrm{~cm}^{2}$, temperature: $\mathrm{T}=45.0^{\circ} \mathrm{C}$ ) Adapted from [67]. 
During these experiments the current was recorded as a function of time at constant electrode potentials and at different electrode rotation rates. Well-defined stationary currents were observed in all cases. The values of the stationary currents depend on the rotating rate of the RDE, the electrode potential, and the temperature.

It should be pointed out that the above measurements were carried out at potentials where the surface concentration of adsorbed $\mathrm{H}$ is very low, if existent. Consequently, it is unlikely that it can play any role. Thus, it should be assumed that the rate-determining step is the decomposition of adsorbed $\mathrm{ClO}_{4}^{-}$with the participation of a free adsorption site.

Figure 4 shows impedance spectra of Ru (deposited on gold) in $1 \mathrm{~mol} \mathrm{dm}^{3} \mathrm{HClO}_{4}$ solution.

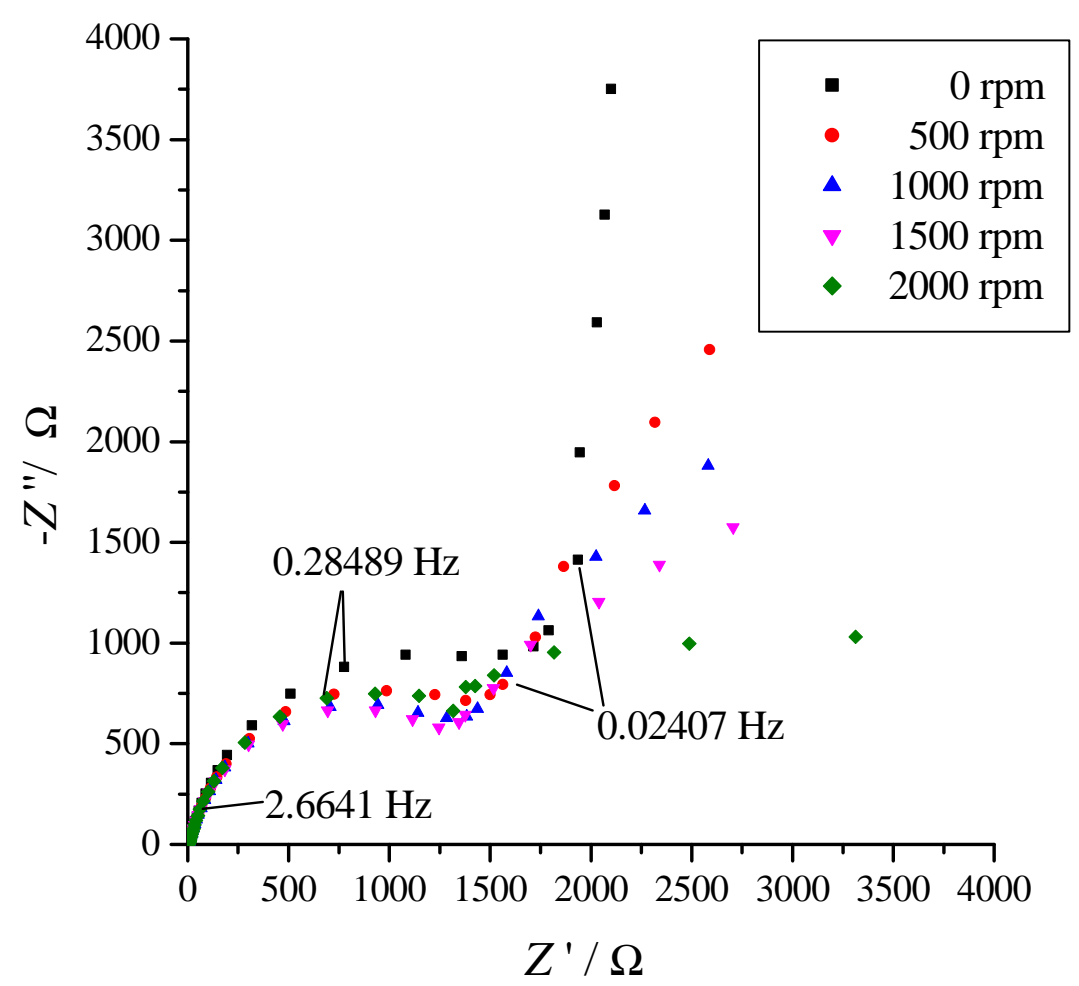

Figure 4. Impedance spectra (complex plane plot) recorded on $\mathrm{Ru}$ in $1 \mathrm{~mol} \mathrm{dm}^{3} \mathrm{HClO}_{4}$ solution. The impedance of the electrode were measured at different rotating rates of the RDE at the electrode potential of $\mathrm{E}=-0.15 \mathrm{~V}$ vs. SSCE. (geometric surface area of the electrode: $\mathrm{A}=0.196 \mathrm{~cm}^{2}$, temperature: $\left.\mathrm{T}=25^{\circ} \mathrm{C}\right)$. (Recent, unpublished results)

The impedance of the electrode was measured at different rotating rates of the RDE at the electrode potential of $\mathrm{E}=-0.15 \mathrm{~V}$ vs. SSCE $\left(T=25^{\circ} \mathrm{C}\right)$. The impedance measurements were started as soon as stationary conditions were reached (e.g. about 20 min after changing the rotation rate of the RDE). The first observation is that the plots are very similar to what is expected qualitatively for the case of a single charge transfer step coupled with diffusion [68].

For all the spectra obtained in this study, only one time constant can be identified in the high frequency range, which suggests that the measured impedance response is dominated by a single (rate determining) charge transfer step. In the case of the reduction of perchlorate ions, the assumption that the $\mathrm{ClO}_{4}^{-} \rightarrow \mathrm{ClO}_{3}^{-}$transformation is the rate determining step seems to be a relevant and acceptable interpretation of the phenomena observed. Experiments with $\mathrm{ClO}_{3}^{-}$ strongly support this hypothesis.

Figure 5 shows cyclic voltammograms obtained for Rh in contact with a solution containing $0.49 \mathrm{~mol} \mathrm{dm}^{-3} \mathrm{NaClO}_{4}+0.01 \mathrm{~mol} \mathrm{dm}^{-3} \mathrm{HClO}_{4}$, and for the same electrode in contact with a solution 
containing $0.49 \mathrm{~mol} \mathrm{dm}^{-3} \mathrm{NaClO}_{3}+0.01 \mathrm{~mol} \mathrm{dm}^{-3} \mathrm{HClO}_{4}$. It can be clearly seen from the figure that in this potential range, the negative current is at least 2 orders of magnitude higher in the presence of $\mathrm{ClO}_{3}^{-}$than the current measured in the other solution. For comparison, the voltammetric curve obtained in $1 \mathrm{~mol} \mathrm{dm}^{-3} \mathrm{HClO}_{4}$ solution is also given in the figure.

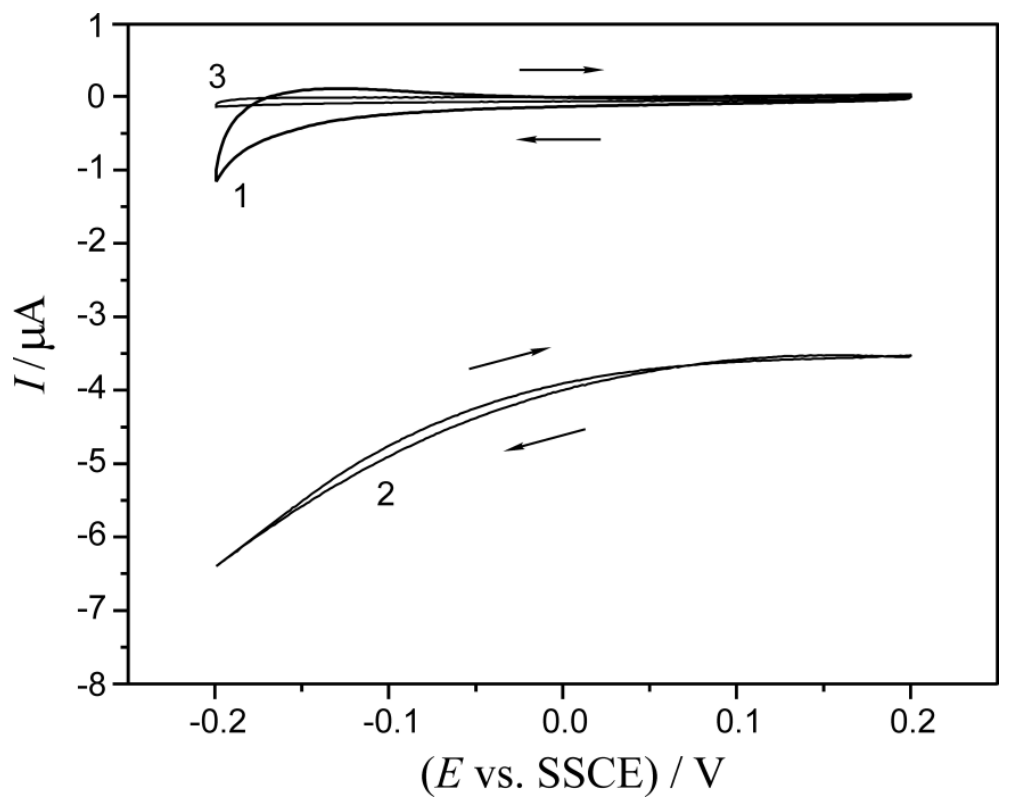

Figure 5. Cyclic voltammograms obtained for $R h(1)$ : in contact with a solution containing $0.49 \mathrm{~mol} \mathrm{dm}^{-3} \mathrm{NaClO}_{4}+0.01 \mathrm{~mol} \mathrm{dm}^{-3} \mathrm{HClO}_{4}$, and (2): for the same electrode in contact with a solution containing $0.49 \mathrm{~mol} \mathrm{dm}^{-3} \mathrm{NaClO}_{3}+0.01 \mathrm{~mol} \mathrm{dm}^{-3} \mathrm{HClO}_{4}$. (3): voltammetric curve obtained in $1 \mathrm{~mol} \mathrm{dm}^{-3} \mathrm{HClO}_{4}$ solution. (geometric surface area of the electrode: $\mathrm{A}=0.196 \mathrm{~cm}^{2}$, temperature: $\mathrm{T}=25.0^{\circ} \mathrm{C}$ ). Adapted from [67].

Electrocatalytic activity in perchlorate reduction was found in the case of some non-noble metals, such as Tc [16], Re [15], Sn [17] and Ti [12,69]. Considering the very fact that Tc is an artificial element, emitting $\beta$-radiation, the coupled electrochemical and radiochemical study of electrodeposition of $\mathrm{Tc}$ species from $\mathrm{HClO}_{4}$ supporting electrolyte gave an interesting insight in the reduction of $\mathrm{ClO}_{4}^{-}$.

It was found that under potentiostatic conditions during the deposition of Tc species, the increase in the radiation intensity, i.e. the increase of the amount of deposited material, is accompanied by a continuous increase of a cathodic current as shown in Figures 6 and 7 (the amount of the electrodeposited Tc species was determined directly by the measurement of the intensity of the radiation coming from the electrodeposited layer).

So far, only the occurrence of $\mathrm{ClO}_{4}^{-}$reduction has been suggested as acceptable explanation [16]. The voltammetric study of the system furnished unambiguous evidence proving the validity of this assumption (Figure 8).

It is well known [70] that the electrochemical behavior and properties of technetium and rhenium and those of their various ions are very similar.

Considering the similarity of $\mathrm{Tc}$ and $\mathrm{Re}$, it was no wonder that the behavior found in the case of Tc can also be observed for Re and vice versa.

In contrast to the behavior of platinized platinum electrodes, the catalytic activity of "rhenized" electrodes can be observed under potentiostatic or galvanostatic conditions for relatively long periods of time, although no real steady state can be attained [15], as is shown in Figure 9 in the case of a potentiostatic experiment. 


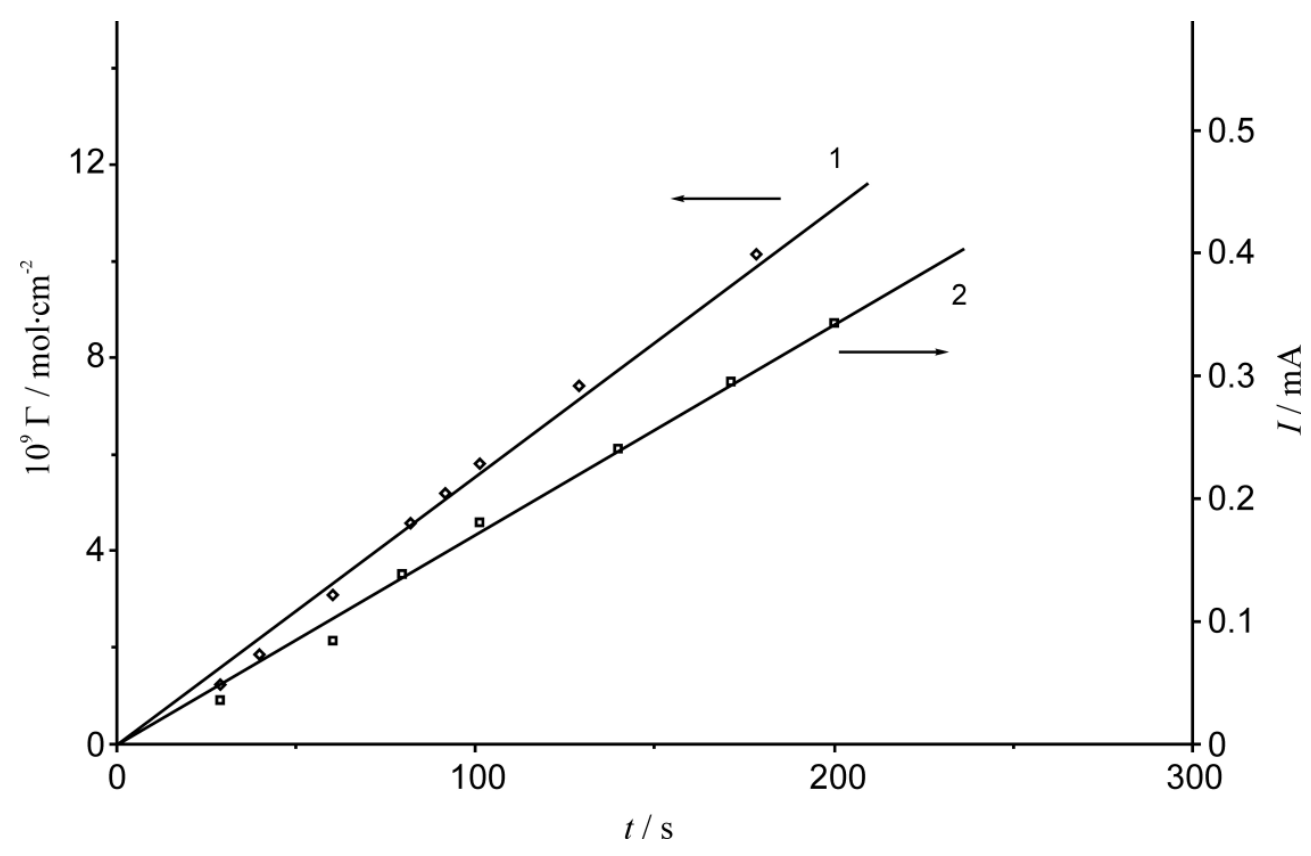

Figure 6. $\Gamma$ vs. time (1) and (absolute value) current vs. time (2) curves obtained in the course of a simultaneous radiometric and electrochemical measurement of the deposition of Tc species $\left(\mathrm{C}_{\mathrm{TCO}_{4}}=8 \times 10^{-4} \mathrm{~mol} \mathrm{dm}^{-3}\right)$ from a $1 \mathrm{~mol} \mathrm{dm}^{-3} \mathrm{HClO}_{4}$ supporting electrolyte at $\mathrm{E}=50 \mathrm{mV}$, (geometric surface area, $13 \mathrm{~cm}^{2}$ ). Adapted from [20].

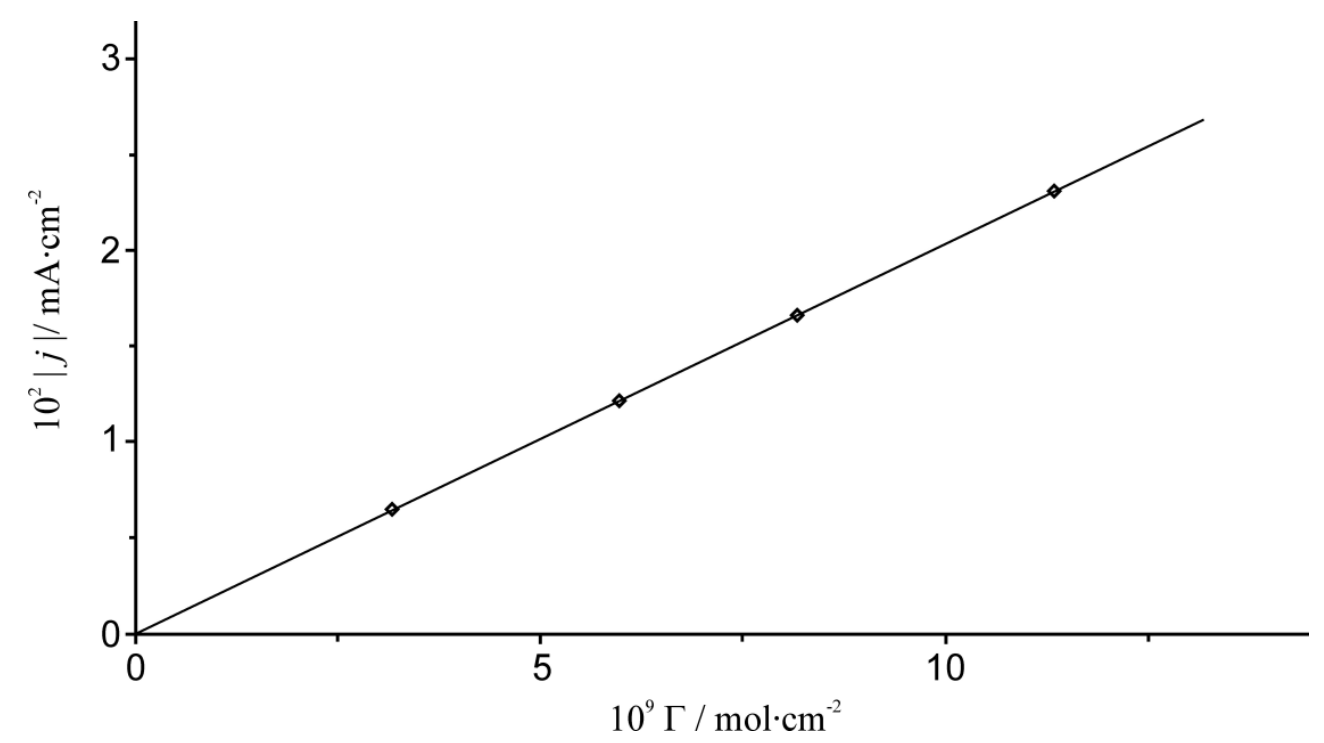

Figure 7. The |j| current density vs. Г relationship obtained from data presented in Figure 6. Adapted from [20]. 


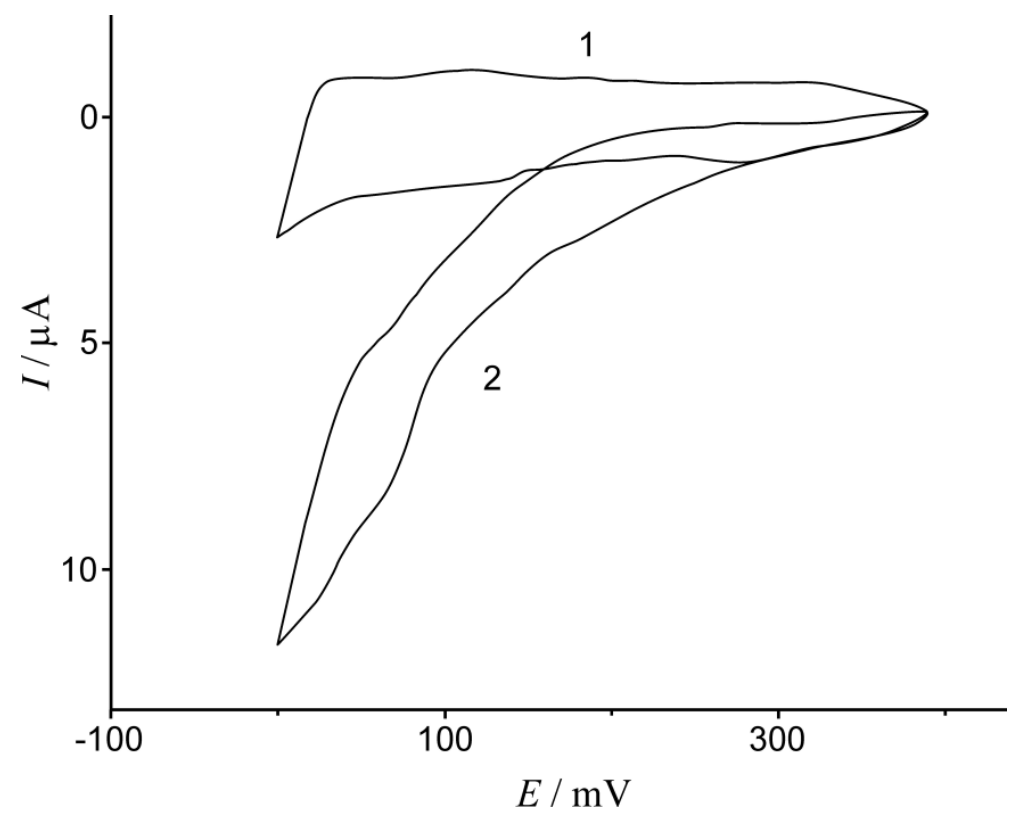

Figure 8. Cyclic voltammetric curves at a Tc-covered surface $\left(\Gamma=2 \times 10^{-8} \mathrm{~mol} \mathrm{~cm}^{-2}\right)$ in $1 \mathrm{~mol} \mathrm{dm}^{-3} \mathrm{H}_{2} \mathrm{SO}_{4}$ (1) and in $3 \mathrm{~mol} \mathrm{dm}^{-3} \mathrm{HClO}_{4}$ (2). Sweep rate, $2.5 \mathrm{mV} \mathrm{s}^{-1}$ (geometric surface area, $13 \mathrm{~cm}^{2}$ ). Adapted from [20].

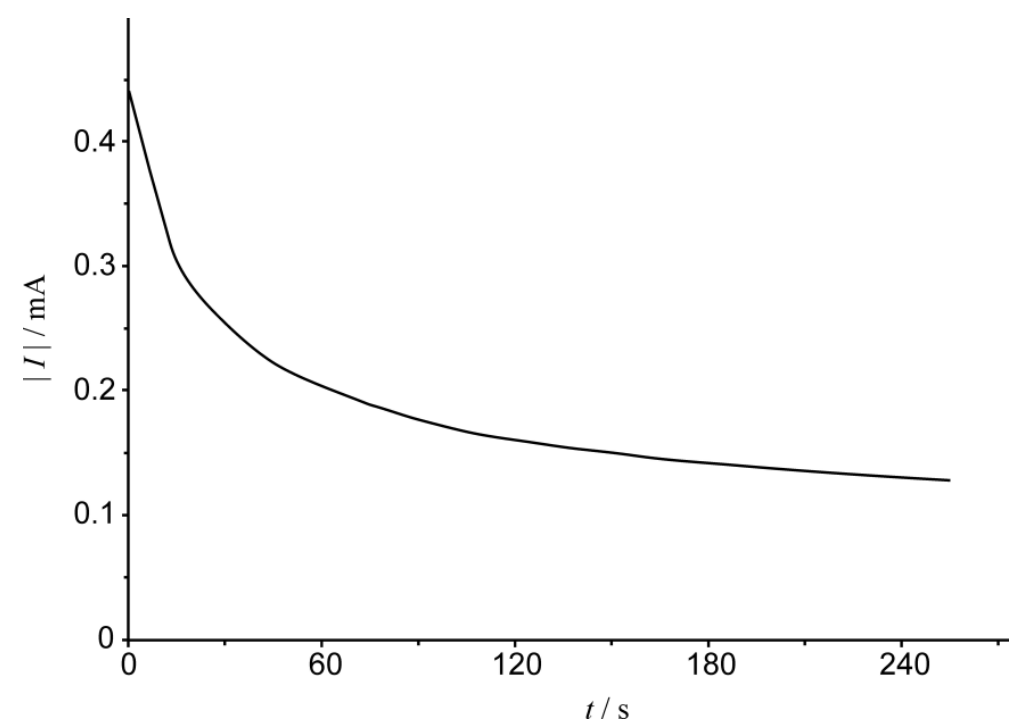

Figure 9. Current vs. time curve obtained in $1 \mathrm{~mol} \mathrm{dm}^{-3} \mathrm{HClO}_{4}$ solution, at $90 \mathrm{mV}$, at a rhenized electrode, (geometric surface area, $2 \mathrm{~cm}^{2}$ ). Adapted from [15].

The continuous decrease in the reduction current can be explained by two important effects:

i) the self-inhibition of the process by the adsorption of $\mathrm{Cl}^{-}$formed in the reduction (the current efficiency with respect to the formation of $\mathrm{Cl}^{-}$is above $\left.90 \%\right)$. The effect of $\mathrm{Cl}^{-}$was demonstrated in separate experiments by adding $\mathrm{HCl}$ in low concentration to the solution phase in the course of the reduction [15], and

ii) deactivation of the electrode surface owing to the chemical transformation of the surface layer participating in the reaction. 
The electrochemical behavior of tin in deaerated sodium perchlorate was studied using potentiodynamic and potentiostatic techniques [17]. The behavior of tin in sodium perchlorate was unexpectedly complicated by the reduction of the perchlorate anion. It was shown that the reduction process takes place within a potential region comprising the negative side of the double layer region and the positive side of the hydrogen region $(-0.7 \leq E \leq-1.3 \mathrm{~V})$. It was stated that the presence of oxide on the electrode surface favors the reduction reaction, which may occur in two steps: the formation of basic tin(II) chloride followed by its reduction, producing chloride.

Similar mechanistic conclusions were drawn in the case of titanium electrode. It was reported that perchlorate ion is electrochemically reduced to chloride ion at an active titanium electrode in aqueous $1.0 \mathrm{M} \mathrm{HClO}_{4}$ [12]. It is assumed that the reduction occurs by direct reaction at the surface rather than a pathway involving catalysis by soluble titanium corrosion products. The reaction occurs by oxygen atom transfer to the titanium surface, and the implications of this mechanism for the surface composition of active titanium electrodes are discussed. Chlorate ion is also reduced at titanium, and the rate coefficient for chlorate reduction is at least $10^{5}$ times greater than that for the perchlorate reduction.

In experiments with $\mathrm{Ti}$ in contact with perchlorate and nitrate solutions, $\mathrm{Ti}(\mathrm{III})$ or $\mathrm{Ti}(\mathrm{II})$ were generated by applying anodic current [69]. These multivalent $\mathrm{Ti}$ species are strong reducing agents and reduce perchlorate and nitrate. Kinetic experiments were carried out in synthetic perchlorate, nitrate solutions, and tap water media at different perchlorate and nitrate concentrations.

\section{Reaction mechanisms and electrode impedance}

In another study [67], the experimental results obtained for the electrochemical reduction of perchlorate ions on rhodium have been explained by the following reaction mechanism. After a potential step from a potential at which the adsorption of $\mathrm{ClO}_{4}^{-}$does not occur, the reduction process starts with the adsorption of perchlorate ions at free active sites on the metal surface occupied, e.g. by $\mathrm{OH}^{-}$.

$$
\mathrm{ClO}_{4}^{-}(\mathrm{sol})+\mathrm{OH}^{-}(\text {ads }) \rightleftarrows \mathrm{ClO}_{4}^{-}(\text {ads })+\mathrm{OH}^{-}(\mathrm{sol})
$$

The decomposition reaction can be written as:

$$
\mathrm{ClO}_{4}^{-}(\text {ads }) \rightarrow \text { intermediates } \rightarrow \mathrm{Cl}^{-}(\text {ads }) \rightleftarrows \mathrm{Cl}^{-} \text {(sol) }
$$

After the production of a certain amount of $\mathrm{Cl}^{-}$, practically all active sites are occupied by $\mathrm{Cl}^{-}$or $\mathrm{ClO}_{4}^{-}$, and a well defined stationary state with constant current is established.

For the stationary state, the following reaction scheme can be suggested:

$$
\begin{array}{ll}
\mathrm{ClO}_{4}^{-}(0)+\mathrm{Cl}^{-}(\text {ads }) \rightleftarrows \mathrm{ClO}_{4}^{-}(\text {ads })+\mathrm{Cl}^{-}(0) & \\
\mathrm{ClO}_{4}^{-}(\text {ads })+2 \mathrm{H}^{+}+2 \mathrm{e}^{-} \rightarrow \mathrm{ClO}_{3}^{-}(\text {ads })+\mathrm{H}_{2} \mathrm{O} & \text { (slow) } \\
\mathrm{ClO}_{3}^{-}(\text {ads }) \rightarrow \text { intermediates } \rightarrow \mathrm{Cl}^{-} \text {(ads) } & \text { (very fast) } \\
\mathrm{Cl}^{-}(0) \rightleftarrows \mathrm{Cl}^{-}(\text {sol }), &
\end{array}
$$

or in a generalized form:

$$
\mathrm{A}^{-}(0)+\mathrm{B}^{-}(\text {ads }) \rightleftarrows \mathrm{A}^{-}(\text {ads })+\mathrm{B}^{-}(0)
$$




$$
\begin{aligned}
& \mathrm{A}^{-}(\text {ads })+n \mathrm{H}^{+}+n \mathrm{e}^{-} \rightarrow \mathrm{B}^{-}(\text {ads })+\frac{n}{2} \mathrm{H}_{2} \mathrm{O} \\
& \mathrm{B}^{-}(0) \rightleftarrows \mathrm{B}^{-} \text {(sol) }
\end{aligned}
$$

where $n$ is the number of electrons transferred from the metal phase to $A^{-}$in forming one $B^{-}$ species, "(ads)" denotes here that the species is adsorbed on an active site, while " $(0)$ " refers to components in the solution phase in the immediate vicinity of the electrode surface [71]. The rate of the first reaction $\left(v_{1}\right)$ depends on the electrode potential $(E)$, the concentration of $A^{-}$and $B^{-}$ near to the electrode surface $\left(c_{A}(0)\right.$ and $\left.c_{B}(0)\right)$, the surface concentration of adsorbed $A^{-}$and $B^{-}$ ions $\left(\Gamma_{\mathrm{A}}\right.$ and $\left.\Gamma_{\mathrm{B}}\right)$, respectively,

$$
v_{1}=v_{1}\left[E, c_{\mathrm{A}}(0), c_{\mathrm{B}}(0), \Gamma_{\mathrm{A}}, \Gamma_{\mathrm{B}}\right] \text {, }
$$

while the rate of the second reaction $\left(v_{2}\right)$ depends on the electrode potential $E, \Gamma_{\mathrm{A}}$ and the concentration of $\mathrm{H}^{+}\left(c_{\mathrm{H}}(0)\right)$ adjacent to the electrode surface:

$$
v_{2}=v_{2}\left[E, \Gamma_{\mathrm{A}}, c_{\mathrm{H}}(0)\right] \text {. }
$$

According to the above considerations

$$
\Gamma_{\mathrm{A}}+\Gamma_{\mathrm{B}}=\Gamma_{\mathrm{T}}
$$

where $\Gamma_{\mathrm{T}}$ is the total surface concentration of the active sites. It can be assumed, that $\Gamma_{\mathrm{T}}$ is constant at a given electrode potential.

Under steady-state conditions $\bar{v}_{1}=\bar{v}_{2}$.

The transport equations for the (linear) diffusion of the species $B^{-}$can be written in the form:

$$
\left(\frac{\partial c_{\mathrm{B}}}{\partial t}\right)_{x}=D_{\mathrm{B}}\left(\frac{\partial^{2} c_{\mathrm{B}}}{\partial x^{2}}\right)_{t}
$$

where $x$ is the distance from the electrode surface.

If the system is perturbed with a sinusoidal signal of low amplitude, the variables can be written in terms of a stationary and a fluctuating component:

$$
\xi(x, t)=\bar{\xi}(x)+\Delta \xi(x) \exp (\mathrm{i} \omega t),
$$

where $\bar{\xi}(x)$ represents the steady-state quantity, $\Delta \xi(x)$ is the amplitude of the fluctuation, $\omega$ is the angular frequency of the perturbing signal, $t$ is the time, and " $i$ " is the imaginary unit. On making an appropriate Taylor series expansion of the reaction rates - with the plausible assumptions

$$
\Gamma_{\mathrm{T}}=\text { constant, }\left(\frac{\partial v_{1}}{\partial c_{\mathrm{A}}(0)}\right) \approx 0 \text { and }\left(\frac{\partial v_{2}}{\partial c_{\mathrm{H}}(0)}\right) \approx 0,
$$

we obtain :

$$
\begin{aligned}
& v_{1}=\bar{v}_{1}+\left(\frac{\partial v_{1}}{\partial E}\right)_{c_{\mathrm{B}}, \Gamma_{\mathrm{B}}} \Delta E \exp (\mathrm{i} \omega t)+\left(\frac{\partial v_{1}}{\partial c_{\mathrm{B}}(0)}\right)_{E, \Gamma_{\mathrm{B}}} \Delta c_{\mathrm{B}}(0) \exp (\mathrm{i} \omega t)+\left(\frac{\partial v_{1}}{\partial \Gamma_{\mathrm{B}}}\right)_{E, c_{\mathrm{B}}} \Delta \Gamma_{\mathrm{B}} \exp (\mathrm{i} \omega t)= \\
& =\bar{v}_{1}+k_{0} \Delta E \exp (\mathrm{i} \omega t)+k_{1} \Delta c_{\mathrm{B}}(0) \exp (\mathrm{i} \omega t)+k_{2} \Delta \Gamma_{\mathrm{B}} \exp (\mathrm{i} \omega t)
\end{aligned}
$$




$$
v_{2}=\bar{v}_{2}+\left(\frac{\partial v_{2}}{\partial E}\right)_{\Gamma_{\mathrm{B}}} \Delta E \exp (\mathrm{i} \omega t)-\left(\frac{\partial v_{2}}{\partial \Gamma_{\mathrm{B}}}\right)_{E} \Delta \Gamma_{\mathrm{B}} \exp (\mathrm{i} \omega t)=\bar{v}_{2}+k_{3} \Delta E \exp (\mathrm{i} \omega t)-k_{4} \Gamma_{\mathrm{B}} \exp (\mathrm{i} \omega t)
$$

Each of the "rate constants" $\left(k_{0}-k_{4}\right)$ appearing in equations (3.9) and (3.10) represents a partial derivative. The "faradaic" current density related to the charge-transfer reaction is given by $i_{\mathrm{F}}=n F v_{2}$. Thus the linearized form of $i_{\mathrm{F}}$ becomes

$$
\Delta i_{\mathrm{F}}=n F\left(k_{3} \Delta E-k_{4} \Delta \Gamma_{\mathrm{B}}\right)
$$

Since $\frac{\partial \Gamma_{\mathrm{B}}}{\partial t}=v_{2}-v_{1}$, thus

$$
\mathrm{i} \omega \Delta \Gamma_{\mathrm{B}}=\left(k_{3}-k_{0}\right) \Delta E-\left(k_{2}+k_{4}\right) \Delta \Gamma_{\mathrm{B}}-k_{1} \Delta c_{\mathrm{B}} .
$$

The linearized form of eq.(7) is :

$$
\mathrm{i} \omega \Delta c_{\mathrm{B}}(x)=D_{\mathrm{B}} \frac{\partial^{2} \Delta c_{B}(x)}{\partial x^{2}} .
$$

The above set of linearized equations (3.9) to (3.12) and the differential equation, (3.13) can be solved analytically $[68,72-74]$ by using the following boundary conditions:

at $x=0$

$$
\Delta J_{B}(0)=-D_{\mathrm{B}} \frac{\partial \Delta c_{\mathrm{B}}(0)}{\partial x}=\Delta v_{1}=k_{0} \Delta E+k_{1} \Delta c_{\mathrm{B}}+k_{2} \Delta \Gamma_{\mathrm{B}}
$$

at $x=\delta$

$$
\Delta c_{\mathrm{B}}(x=\delta)=0
$$

where $\delta$ represents the diffusion layer thickness, and $J_{B}$ is the flux of species $\mathrm{B}^{-}$.

The resulting expression for the "faradaic" admittance is quite complicated:

$$
Y_{\mathrm{F}}(\omega)=Y_{1}(\omega)+Y_{2}(\omega)=n F k_{3}\left(1-\frac{k_{4}}{\mathrm{i} \omega+k_{2}+k_{4}+\frac{k_{1} k_{2}}{Q-k_{1}}}\right)+n F k_{4} \frac{k_{0}-\frac{k_{1} k_{0}}{k_{1}-Q}}{\mathrm{i} \omega+k_{2}+k_{4}+\frac{k_{1} k_{2}}{Q-k_{1}}}
$$

with $Q=\frac{D s[\exp (2 s \delta)+1]}{\exp (2 s \delta)-1}$ and $s=\sqrt{\frac{\mathrm{i} \omega}{D_{\mathrm{B}}}}$

The first term of the right hand side of equation (3.16) can be rewritten as $Y_{1}(\omega)=1 / Z_{1}(\omega)$, where the impedance function $Z_{1}(\omega)$ can be expressed by

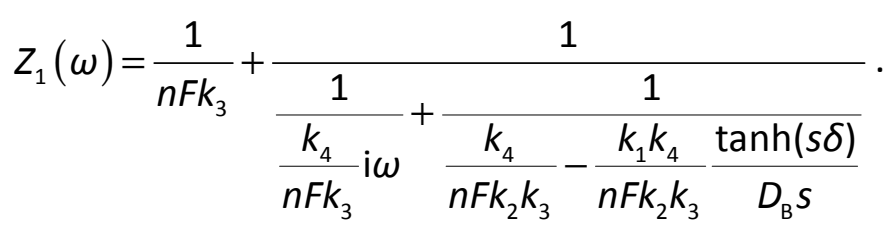

The second term can be written as $Y_{2}(\omega)=1 / Z_{2}(\omega)$, where

$$
Z_{2}(\omega)=\frac{1}{n F} \frac{k_{2}+k_{4}}{k_{0} k_{4}}-\frac{k_{1}}{n F k_{0}} \frac{\tanh (s \delta)}{D_{\mathrm{B}} s}-\frac{k_{1} s}{n F k_{0} k_{4}} \tanh (s \delta) \text {. }
$$


Thus, the faradaic impedance of the electrode $\left(Z_{\mathrm{F}}\right)$ is given as

$$
Z_{\mathrm{F}}(\omega)=\frac{1}{1 / Z_{1}(\omega)+1 / Z_{2}(\omega)}
$$

In a general case, the impedance function completed by elements representing the ohmic resistance $\left(R_{\mathrm{u}}\right)$ of the electrolyte solution and the double layer capacitance $\left(C_{\mathrm{dl}}\right)$ can be written as:

$$
Z_{\mathrm{T}}(\omega)=R_{\mathrm{u}}+\left[\frac{1}{Z_{1}(\omega)}+\frac{1}{Z_{2}(\omega)}+\mathrm{i} \omega C_{\mathrm{dl}}\right]^{-1}
$$

The impedance function of the double layer in such type of electrochemical systems can be well approximated by $Z_{\mathrm{dl}}(\omega)=\left(\mathrm{i} \omega A_{\mathrm{dl}}\right)^{-\beta}$, where $\beta \leq 1$ (but it is close to 1 ) [75]. Thus,

$$
Z_{\mathrm{T}}(\omega)=R_{\mathrm{u}}+\left[\frac{1}{Z_{1}(\omega)}+\frac{1}{Z_{2}(\omega)}+\left(i \omega A_{\mathrm{dl}}\right)^{6}\right]^{-1},
$$

In principle, it is possible to estimate the parameters of equation (3.21) from the measured impedance data by complex nonlinear fitting. However, the complete expression of the impedance (equation (3.20)) contains 10 free parameters, and the fitting in the case of such a high number of parameters is always a very difficult task. In addition, due to the mathematical structure of equation (3.21), the parameters are expected to be strongly correlated [76]. In order to overcome the difficulties concerning CNLS fitting, simplifications in the mathematical expressions should be introduced. It may be assumed that $k_{0}$ is very small, therefore $Z_{2}(\omega)$ can be neglected or approximated by an ohmic resistance: $Z_{2}(\omega) \approx R_{k}$.

On the other hand, by substituting

$$
R_{\mathrm{ct}}=\frac{1}{n F k_{3}}, C_{\mathrm{A}}=\frac{k_{4}}{n F k_{3}}, R_{\mathrm{A}}=\frac{k_{4}}{n F k_{2} k_{3}}, P_{1}=-\frac{k_{1} k_{4}}{n F k_{2} k_{3} \sqrt{D_{\mathrm{B}}}} \text {, and } P_{0}=\delta / \sqrt{D_{\mathrm{B}}}
$$

into equation (17), we have

$$
Z_{1}(\omega)=\frac{1}{R_{\mathrm{ct}}}+\frac{1}{\frac{1}{\mathrm{i} \omega C_{\mathrm{A}}}+\frac{1}{R_{\mathrm{A}}+P_{1} \frac{\tanh \left(P_{0} \sqrt{\mathrm{i} \omega}\right)}{\sqrt{\mathrm{i} \omega}}}}=\frac{1}{R_{\mathrm{ct}}}+\frac{1}{\frac{1}{\mathrm{i} \omega C_{\mathrm{A}}}+\frac{1}{R_{\mathrm{A}}+Z_{\mathrm{w}}}} .
$$

The equivalent circuit analog [77] corresponding to the analytical expression given by equation (3.21) is presented in Figure 10.

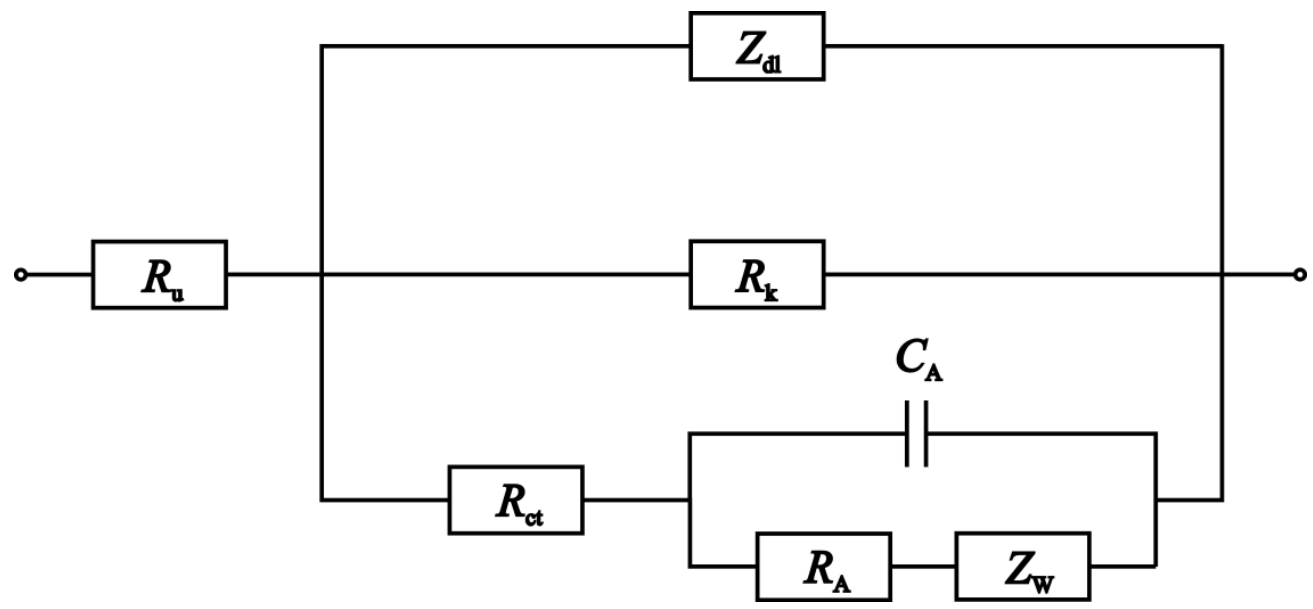


Figure 10. The equivalent circuit analog.

Detailed numeric results of the CNLS fittings are presented in the study by Ujvári et al [78]. Surprisingly, despite of the great number of adjustable parameters, many of them could be determined with a good statistics (for instance $R \mathrm{u}, P_{0}, R_{\mathrm{A}}, C_{\mathrm{A}}, P_{\mathrm{l}}, A_{\mathrm{d} l}, 6$, ), and reasonable estimated mean values have been obtained for the others.
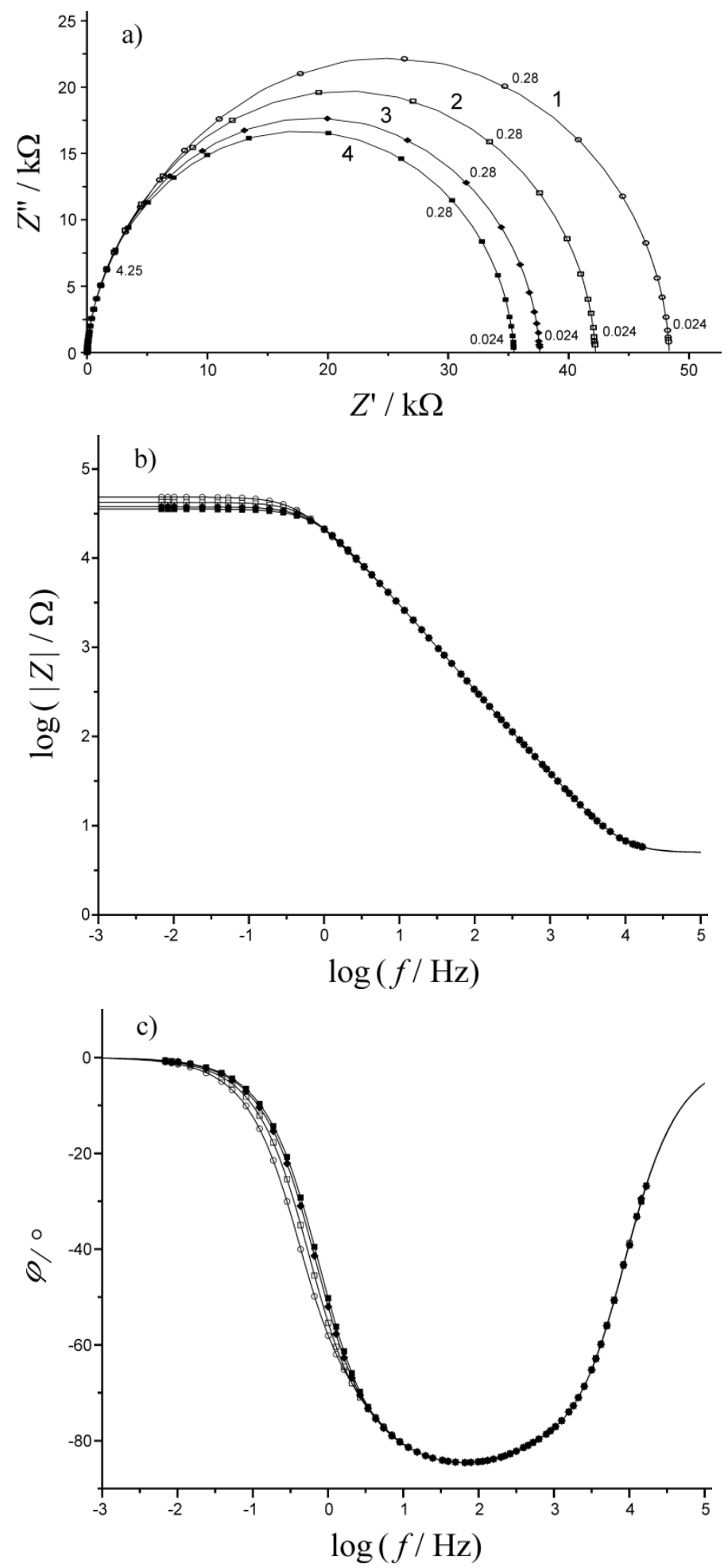

Figure 11. (a) Impedance spectra (complex plane plots) recorded on $\mathrm{Rh}$ in $1 \mathrm{~mol} \mathrm{dm}^{3} \mathrm{HClO}_{4}$ solution. The impedance of the electrode were measured at different rotating rates of the RDE at the electrode potential of $\mathrm{E}=0.01 \mathrm{~V}$ vs. SSCE. $\left(T=25.0^{\circ} \mathrm{C}\right)$. Rotation rates $\left(\omega_{r}\right): 1(\mathrm{O}): 500$ rpm; 2 ( $\square$ ): 1000 rpm; 3 (•): 2000 rpm; 4 (•): 3000 rpm. (b) - (c) Bode diagrams (log/Z/ versus 
$\log f$ and $\varphi$ versus log $\mathrm{f}$ plots) at 4-4 different rotation rates of the RDE. Continuous lines: simulated curves calculated by using the optimized parameters. Adapted from [67].

Figures $11 \mathrm{~b}$ and $11 \mathrm{c}$ show the Bode diagrams ( $\log |Z|$ versus $\log f$ and $\varphi$ versus $\log f$ plots) at 4-4 different rotation rates of the RDE, respectively $\left(E=0.01 \mathrm{~V}\right.$ vs. SSCE, $\left.T=25{ }^{\circ} \mathrm{C}\right)$. The Argand diagrams (complex impedance plane plots) are presented in Figure 11a. In Figures 11a-11c, beside the measured values (discrete points), the simulated curves calculated by using the optimized parameters are also displayed (continuous lines). The "visual" inspection of the transformed curves (Bode plots) supplies more valuable information concerning the goodness of a fit than that of the complex plane plot, since complex plane plots usually show a rather "good" fit, while the transformed curves reveal the problems. The physical reality of the parameters is perhaps the most important criterion in checking the correctness of a model. The variation of the appropriate fitting parameters with rotating rates of the RDE could be very informative. Particularly the changes observed in $C_{\mathrm{A}}$ and $P_{0}$ are of special interest. $C_{\mathrm{A}}$ increases monotonically with the rotation rate, as expected for decreasing concentration of chloride ions in the immediate vicinity of the electrode surface. The $P_{0}$ vs. $\omega_{\mathrm{r}}^{-1 / 2}$ plot is linear.

\section{Reduction of perchlorate ions in the course of anodic dissolution and corrosion of metals}

Most studies concerning the basics of the anodic dissolution of metals focused on relatively simple systems [79]. "Simple systems" ideally consist of single-crystalline or polycrystalline, highly pure metals in acid aqueous solutions free of dissolved oxygen, surface-active substances, and complexing agents. The dissolution behavior in alkaline or neutral media, even in deaerated or aerated aqueous solutions free of surface-active and complexing substances, is difficult to study because of the easy formation and slow dissolution of protective layers. Also, the influence of surface-active substances on the dissolution kinetics and mechanisms of metals is better known in acid than in neutral or alkaline environments.

It is an almost general conclusion drawn from anodic dissolution studies that the nature of anions present in the electrolyte solutions affects the dissolution process to a more or less pronounced extent.

In most mechanistic considerations, this effect is explained by the role of the specific adsorption of anions. Accepting this assumption, and taking into consideration that the adsorbability of the anions on metals is very different depending on the nature of the anion, it would be important to study the dissolution process in the presence of anions with very low adsorbability in order to minimize the role of anion adsorption in the dissolution process, consequently, to obtain experimental data without the interference of anion specific adsorption. According to some very recent views, $\mathrm{ClO}_{4}^{-}$are assumed to fulfill this requirement $[80,81]$.

On the basis of the assumption of stability of $\mathrm{ClO}_{4}^{-}$sophisticated electrochemical methods, such as EQCM and electrochemical impedance spectroscopy (EIS), were used for the study of anodic dissolution and corrosion of various metals in perchloric acid solutions, for instance, in the case of nickel [82] and iron [80,81].

Detailed mechanistic conclusions are drawn from such studies without taking into account the possible reduction of $\mathrm{ClO}_{4}^{-}$under the conditions of the experiments.

In a series of communications [83-85], the authors pointed out that the reduction of $\mathrm{ClO}_{4}^{-}$takes place during the corrosion of $\mathrm{Cu}, \mathrm{Al}, \mathrm{Zn}, \mathrm{Ni}$, and $\mathrm{Fe}$ in deoxygenated $\mathrm{HClO}_{4}$ solutions and emphasized that, for the interpretation of the results of corrosion or anodic dissolution studies in the $\mathrm{HClO}_{4} /$ metal systems, this fact cannot be left out of consideration. Presence of chlorate and 
perchlorate ions leads to passivity breakdown and pitting corrosion of iron in sulfuric acid solutions [86]. The origin of the pitting has been attributed to $\mathrm{Cl}^{-}$produced via the reduction of $\mathrm{ClO}_{3}^{-}$and $\mathrm{ClO}_{4}^{-}$by $\mathrm{Fe}^{2+}$. Similar results were obtained for $\mathrm{Al}$ in [87]. The XPS experiments detected perchlorate and chloride ions on the surface. Both of these ions may play role in the passivity breakdown.

Oscillatory electrodissolution of Al in perchloric acid solutions has been described [88]. According to the authors, current oscillations occurred over a large range of $\mathrm{HClO}_{4}$ concentration and over a wide scale of applied potential. During the anodic dissolution of the Al electrode in $\mathrm{HClO}_{4}$ solutions, perchlorate ions were reduced to chloride ions, which induced pitting corrosion.

The electrodeposition of $\mathrm{Cu}$ on $\mathrm{Ru}(0001)$ in perchlorate media has also been investigated [89]. XPS was used to determine surface composition. The spectra show that $\mathrm{ClO}_{4}^{-}$dissociates into adsorbed $\mathrm{Cl}^{-}$and $\mathrm{ClO}_{x}^{-}$species.

The composition of the passive layers formed on $\mathrm{Zn}$ electrode in naturally aerated and deaerated $0.1 \mathrm{M} \mathrm{KClO}_{4}$ solution were studied using chronopotentiometry, electrochemical impedance, and X-ray photoelectron spectroscopic measurements (XPS). $\mathrm{Cl}^{-}$from the perchlorate reduction reaction were detected in the solutions during electrode polarization [90,91].

\section{Interaction of $\mathrm{ClO}_{4}^{-}$with iron group metals in aqueous media}

The dissolution kinetics and mechanism of iron-group metals has been investigated in a great number of studies [79-82,92].

The kinetics of the anodic dissolution of iron, cobalt, and nickel was found to be quite similar and a common mechanistic picture can be used for the interpretation of phenomena occurring with these metals.

In the 1960s, Göhr and Kruger investigated the behavior of cobalt in perchloric acid solution using measurements carried out under controlled potential and current $[93,94]$. The results were interpreted on the basis of thermodynamic data. It was concluded that at open circuit and at small polarizations cobalt corrodes exclusively with hydrogen evolution. The possibility of the reduction of $\mathrm{ClO}_{4}^{-}$under these conditions was not considered as a physical reality.

Similar conclusions were drawn in case of other iron-group metals as presented in the survey article by Lorenz and Heusler devoted to the problems of the dissolution of iron-group metals [79]. On the other hand, it is an almost generally accepted view that the nature of the anions present in the solution phase in contact with the dissolving metal plays an important role in the kinetics and mechanism of the dissolution process.

It is assumed that the main factor determining the effect of anions in these reactions is the adsorbability of the anion, i.e. the direct interaction of anions with the metal surface. Generally, it is assumed that this interaction does not lead to the chemical transformation of the anion. It is also assumed that the adsorbability of $\mathrm{ClO}_{4}^{-}$on iron-group metals is very low; thus, the adsorption of other anions can be studied in the presence of perchlorate supporting electrolyte without significant role of adsorption competition.

However, the validity of this assumption could be questioned in the light of some recent studies [20] and revisiting some results reported in the literature more than fifty years ago [95,96].

As mentioned above, the problem of perchlorate contamination of ground waters is nowadays an important environmental issue [24,37-39], and several methods were suggested and elaborated for reductive elimination of $\mathrm{ClO}_{4}^{-}$. One of these methods, reported quite recently, is the reduction with metallic iron. The results obtained from these practical studies can be 
considered convincing evidence of the reduction interaction of $\mathrm{Fe}$ with $\mathrm{ClO}_{4}^{-}$. Results with $\mathrm{Co}$ prove that the rate and extent of the reduction process could also be very characteristic [97]. Under suitable chosen experimental conditions, even this process could be the predominant reaction in the dissolution of metallic cobalt in the presence of $\mathrm{ClO}_{4}^{-}$.

In contrast to $\mathrm{Fe}$ and $\mathrm{Co}$, a relatively slow reduction was found in the presence of $\mathrm{Ni}$ [83]. Nevertheless, it can be stated unambiguously that $\mathrm{ClO}_{4}^{-}$dissolved in acidic aqueous solutions can be reduced with $\mathrm{Ni}$ [83], Fe [98], and Co [97] metals. According to [99], significant reduction of perchlorate to chloride ions occurred on the nickel cathode in a cell with a nickel working electrode and a platinum counter electrode in concentrated solutions of $\mathrm{HClO}_{4}$. It has been shown that the mechanism of this process involves platinum deposited in small amounts on the cathode as a result of oxidation of the platinum anode in the perchloric acid solution. The reduction of perchlorate was accompanied by oxidation of the nickel cathode, which can be attributed to chlorate ions formed in the initial step of perchlorate reduction.

To estimate the relative role of $\mathrm{ClO}_{4}^{-}$reduction in the overall dissolution process of $\mathrm{Ni}$, $\mathrm{Fe}$, and Co, we summarized some data obtained in previous studies of metal-perchlorate (perchloric acid) interaction (Table 2). It may be seen that the rate of the formation of $\mathrm{Cl}^{-}$from $\mathrm{ClO}_{4}^{-}$is relatively low in the case of $\mathrm{Ni}$ at ambient temperature, while for $\mathrm{Fe}$ and $\mathrm{Co}$, depending on the experimental conditions, the reduction of $\mathrm{ClO}_{4}^{-}$could play a substantial role in the overall process. Considering this situation, it could be expected that the results of the usual corrosion measurements carried out in the presence of acidic perchlorate solution should reflect this role in the case of Co and Fe.

Table 2. Interaction of $\mathrm{Ni}, \mathrm{Fe}$, and $\mathrm{Co}$ with $\mathrm{ClO}_{4}^{-}$at $\mathrm{T}=25^{\circ} \mathrm{C}$

\begin{tabular}{|c|c|c|c|c|c|c|}
\hline & \multicolumn{2}{|c|}{ Electrolyte } & \multirow{2}{*}{$\begin{array}{c}\text { A } \\
\text { Chemical amount } \\
\text { corresponding to the mass } \\
\text { of dissolved metal, mol }\end{array}$} & \multirow{2}{*}{$\begin{array}{c}\text { B } \\
\text { Chemical amount of } \mathrm{Cl}^{-} \\
\text {formed during the } \\
\text { dissolution of metal, mol }\end{array}$} & \multirow[b]{2}{*}{$B / A$} & \multirow[b]{2}{*}{ Conversion* / \% } \\
\hline & $\mathrm{HClO}_{4} / \mathrm{M}$ & $\mathrm{NaClO}_{4} / \mathrm{M}$ & & & & \\
\hline \multirow{2}{*}{$\mathrm{Ni}$} & 3 & & $3.57 \times 10^{-2}$ & $7.5 \times 10^{-5}$ & $2.1 \times 10^{-3}$ & 0.84 \\
\hline & 1 & & $1.26 \times 10^{-2}$ & $2.6 \times 10^{-5}$ & $2.0 \times 10^{-3}$ & 0.80 \\
\hline \multirow{5}{*}{$\mathrm{Fe}$} & 1 & 2 & $1.80 \times 10^{-3}$ & $8.6 \times 10^{-5}$ & $4.77 \times 10^{-2}$ & 19.6 \\
\hline & 0.1 & 2.9 & $5.73 \times 10^{-4}$ & $4.56 \times 10^{-5}$ & $7.96 \times 10^{-2}$ & 31.8 \\
\hline & 0.1 & 0.9 & $4.48 \times 10^{-4}$ & $2.92 \times 10^{-5}$ & $6.52 \times 10^{-2}$ & 26.1 \\
\hline & 0.5 & 0 & $4.48 \times 10^{-4}$ & $2.96 \times 10^{-5}$ & $6.61 \times 10^{-2}$ & 26.4 \\
\hline & 1 & 0 & $1.27 \times 10^{-3}$ & $5.75 \times 10^{-5}$ & $4.53 \times 10^{-2}$ & 18.1 \\
\hline \multirow{3}{*}{ Co } & 1 & 0 & $9.48 \times 10^{-4}$ & $4.95 \times 10^{-5}$ & $5.2 \times 10^{-2}$ & 20.1 \\
\hline & 4 & 0 & $14.45 \times 10^{-4}$ & $15.74 \times 10^{-5}$ & $1.09 \times 10^{-1}$ & 43.5 \\
\hline & 0.1 & 1.9 & $11.73 \times 10^{-4}$ & $9.54 \times 10^{-5}$ & $8.1 \times 10^{-2}$ & 32.5 \\
\hline
\end{tabular}

* The percentage of dissolved metal involved in $\mathrm{ClO}_{4}^{-}$reduction (see text).

The data presented in the Table 2 were obtained using metal powders. Thus, they should be considered as average values as during the dissolution process the parameters of the systems are changing continuously. Some of these factors are as follows:

i) The $\mathrm{H}^{+}$concentration is changing according to the following equation 
$c_{\mathrm{H}^{+}}=c_{\mathrm{H}^{+}}^{0}-8 c_{\mathrm{Cl}}-2\left(c_{\mathrm{Co}^{2+}}-4 c_{\mathrm{Cl}^{2}}\right)=c_{\mathrm{H}^{+}}^{0}-2 c_{\mathrm{CO}^{2+}}$

ii) The surface area of the metal powder is changing in the course of the dissolution process [100].

The change in the $\mathrm{H}^{+}$concentration could be very important at low initial $\mathrm{HClO}_{4}$ concentrations. For instance, taking into consideration the data reported in Table 2 for the dissolution of Co at $0.1 \mathrm{~mol} \mathrm{dm}^{-3} \mathrm{HClO}_{4}$ concentration at $25^{\circ} \mathrm{C}$ using $25 \mathrm{ml}$ solution, the final $\mathrm{H}^{+}$concentration is

$$
c_{\mathrm{H}^{+}}=(0.10-0.094)=6 \times 10^{-3} \mathrm{~mol} \mathrm{dm}^{-3} \text {. }
$$

This means that at the end of the dissolution experiment, the hydrogen ion concentration is more than one order of magnitude lower than that in the initial state.

Only in the case of high $\mathrm{H}^{+}$concentration $\left(4 \mathrm{~mol} \mathrm{dm}^{-3}\right)$ can be expected a practically constant acidity during the whole dissolution experiment. The problems caused by the $\mathrm{H}^{+}$consumption are well reflected in the temperature dependence of the conversion of $\mathrm{ClO}_{4}^{-}$to $\mathrm{Cl}^{-}$in the presence of Co powder.

At low $\mathrm{HClO}_{4}$ concentrations ( 0.1 and $1 \mathrm{~mol} \mathrm{dm}^{-3}$ ), the scattering of the data is remarkable, while in the case of a solution of $4 \mathrm{~mol} \mathrm{dm}^{-3} \mathrm{HClO}_{4}$, a monotonous increase can be observed.

The change in the $\mathrm{pH}$ influences not only the rate of the perchlorate reduction - metal dissolution, but also the adsorption of the produced $\mathrm{Cl}^{-}$. The adsorption phenomena were studied on powdered metals [100]. The principle of the method used was the measurement of radiation intensity originating from labeled adsorbed species on a powdered metal layer sprinkled on a thin plastic foil that serves simultaneously as the window for radiation measurement. The measurements were carried out at ambient temperature in an $\mathrm{Ar}$ atmosphere. Radiotracer experiments at different $\mathrm{H}^{+}$-ion concentrations can be seen in Figure 12. The adsorption of $\mathrm{Cl}^{-}$ decreases with the $\mathrm{pH}$.

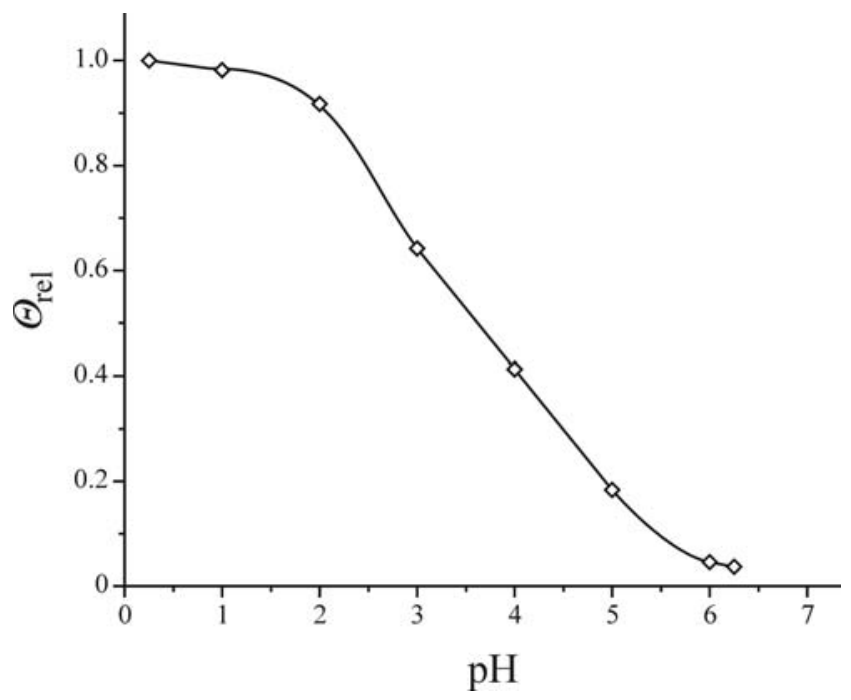

Figure 12. The $\mathrm{pH}$ dependence of the adsorption of chloride ions (on relative scale) on Co.

It should be noted, however, that attempting the study of the adsorption of labeled $\mathrm{Cl}^{-}$on powdered $\mathrm{Co}$ in $0.5 \mathrm{M} \mathrm{NaClO}_{4}$ solution at low $\mathrm{pH}$ values, for instance, $\mathrm{pH} \approx 2$ (by addition of $\mathrm{HClO}_{4}$ ) the count-rate vs. time curves (curves 1, 2 and 3 in Figure 13) going through maximum were obtained. 


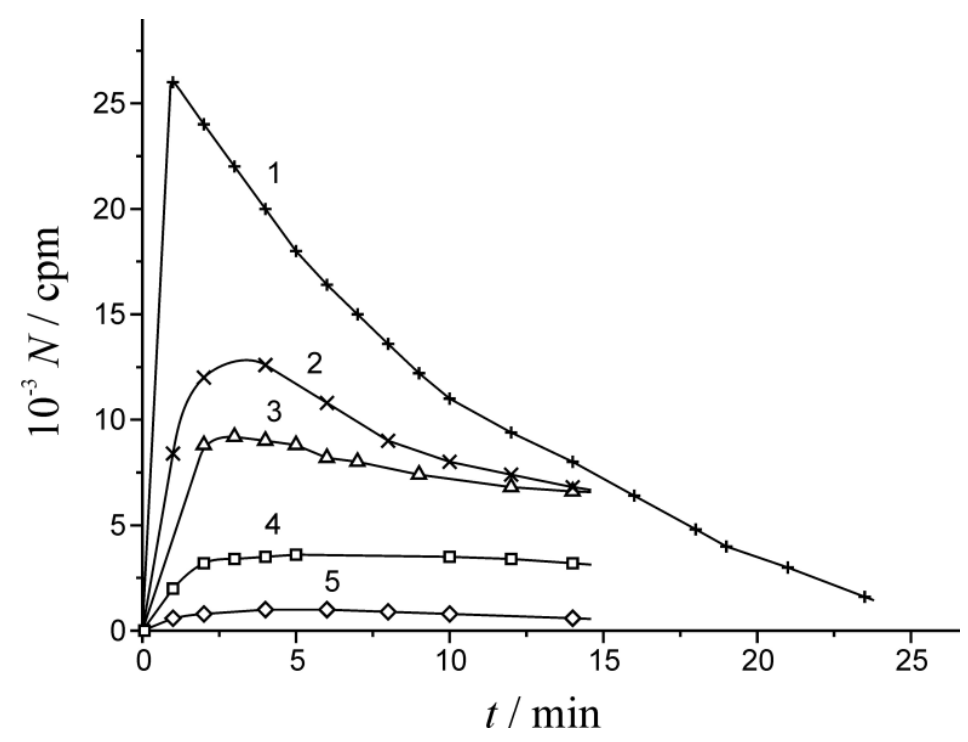

Figure 13. Count-rate vs. time curves obtained following the addition of $0.25 \mathrm{ml} 1 \mathrm{~mol} \mathrm{dm}^{-3}$ $\mathrm{HClO}_{4}$ to a solution of $0.5 \mathrm{~mol} \mathrm{dm}^{-3} \mathrm{NaClO}_{4}+1 \times 10^{-4} \mathrm{~mol} \mathrm{dm}^{-3}$ labeled $\mathrm{Cl}^{-}$in contact with $0.5 \mathrm{~g}$ Co powder. (1) First run, (2) second run, (3) third run, (4) addition of $1 \times 10^{-4} \mathrm{~mol} \mathrm{NaCl}$, (5) addition of $5 \times 10^{-4} \mathrm{~mol} \mathrm{NaCl}$. Adapted from [98].

The decrease in the count-rate means that no equilibrium or steady state is attained with respect to the surface concentration of the isotope emitting the radiation. This phenomenon can be explained by the production of inactive $\mathrm{Cl}^{-}$(i.e. by the decrease of specific activity of $\mathrm{Cl}^{-}$ species). The displacement of the active species by non-active ones occurs immediately at the surface and this could be the very reason for the rapid decrease of the count-rate in the case of curve (1).

In the course of the corrosion, the $\mathrm{pH}$ also shifts from the initial $\mathrm{pH} \approx 2$ value to higher ones. In order to demonstrate that the decrease in the count-rate is mainly determined by the production of inactive $\mathrm{Cl}^{-}, \mathrm{HClO}_{4}$ was added again to the solution phase shifting the $\mathrm{pH}$ to the original value. The results of this procedure presented by curves 2 and 3 in Figure 13 show that the maximum in the count-rate is significantly lower than that for curve 1 and that the maxima are less pronounced in the two former cases. This observation is in agreement with the assumption of the production of $\mathrm{Cl}^{-}$. It is evident that with decreasing specific activity the "isotopic dilution" caused by the production of further $\mathrm{Cl}^{-}$becomes less and less pronounced and this is reflected by the position and shape of the maxima on curves 1,2 , and 3.

Curves 4 and 5 in Figure 13 were obtained following the addition of inactive $\mathrm{NaCl}$ to the solution phase. In this case, the "isotopic dilution" was carried by direct addition of inactive $\mathrm{Cl}^{-}$. The effect observed is in accordance with the expectation. In the course of the corrosion of Co powder, $\mathrm{Cl}^{-}$are formed from the $\mathrm{ClO}_{4}^{-}$. Thus, the $\mathrm{pH}$ dependence presented in Figure 12 was determined starting from $\mathrm{pH}=6$ and measuring the radiation intensity only a short period following a shift of $\mathrm{pH}$ to a preselected value. For more details about anion adsorption see Ref. [101].

\section{Conclusion}

The experimental evidence collected during the previous decades unambiguously indicates that the electrochemical stability of perchlorate ions holds no promise. Starting from this statement, experimental data and theoretical considerations based on the concept of stability of $\mathrm{ClO}_{4}^{-}$should be rigorously revised, given the large number of such publications in the electrochemical 
literature. On the other hand, the electrochemical treatment method is one of the ways considered as applicable for solving the perchlorate contamination problem.

Acknowledgements: Financial support from Hungarian Scientific Research Fund (OTKA) is acknowledged (OTKA-67994/OMFB-01078/2007 and PD75445).

\section{References}

[1] S. Ya. Vasina, O. A. Petrii, Elektrokhim. 6 (1970) 242-246.

[2] G. Horányi, E. M. Rizmayer, J. Electroanal. Chem. 198 (1986) 379-391.

[3] C. K. Rhee, M. Wasberg, G. Horányi, A. Wieckowski, J. Electroanal. Chem. 291 (1990) 281287.

[4] C. K. Rhee, M. Wasberg, P. Zelenay, A. Wieckowski, Catal. Lett. 10 (1991) 149-164.

[5] J. Clavilier, M. Wasberg, M. Petit, L. H. Klein, J. Electroanal. Chem. 374 (1994) 123-131.

[6] I. Bakos, G. Horányi, J. Electroanal. Chem. 332 (1992) 147-154.

[7] G. Horányi, I. Bakos, React. Kinet. Catal. L. 46 (1992) 139-144.

[8] G. Horányi, I. Bakos, J. Electroanal. Chem. 331 (1992) 727-737.

[9] G. Horányi, G. Vértes, J. Electroanal. Chem. 64 (1975) 252-254.

[10] G. Horányi, G. Vértes, Inorg. Nucl. Chem. Lett. 10 (1974) 767-770.

[11] J. Paoinot, J. Augustynski, Electrochim. Acta 20 (1975) 747-752.

[12] G. M. Brown, J. Electroanal. Chem. 198 (1986) 319-330.

[13] M. Sanches Cruz, M. J. Gonzalez Tejera, M. C. Villamanan, Electrochim. Acta 30 (1985) 1563-1569.

[14] F. Colom, M. J. Gonzalez Tejera, J. Electroanal. Chem. 190 (1985) 243-255.

[15] I. Bakos, G. Horányi, S. Szabó, E. M. Rizmayer, J. Electroanal. Chem. 359 (1993) 241-252.

[16] G. Horányi, I. Bakos, J. Appl. Electrochem. 23 (1993) 547-552.

[17] C. M. V. B. Almeida, B. F. Giannetti, T. Rabockai, J. Electroanal. Chem. 422 (1997) 185-189.

[18] G. Horányi, I. Bakos, ACH-Models Chem. 131 (1994) 25-41.

[19] G. Horányi, in Catalysis; A Specialist Periodical Report (J. J. Spivey, Ed.) The Royal Society of Chemistry, Cambridge, GB. 1996; Vol. 12, pp. 254-301.

[20] G. G. Láng, G. Horányi, J. Electroanal. Chem. 552 (2003) 197-211.

[21] G. M. Brown, B. Gu, in Perchlorate, Environmental Occurence, Interactions and Treatment, (B. Gu, J.D. Coates Eds.) Springer Publishers, 2006, pp.17-47.

[22] U.S. Environmental Protection Agency (US EPA), EPA report, Perchlorate Environmental Contamination: Toxicological Review and Risk Characterization, 2002.

[23] I. H. Yoon, X. Meng, C. Wang, K.W. Kim, S. Bang, E. Choe, L. Lippincott, J. Hazard. Mater. 164 (2009) 87-94.

[24] E. T. Urbansky, Perchlorate in the Environment, Kluwer Academic Publisher, Dordrecht, 2001.

[25] E. T. Urbansky, Environ. Sci. Pollut. R. 9 (2002) 187-192.

[26] E. T. Urbansky, M.R. Schock, J. Environ. Manage. 56 (1999) 79-95.

[27] C. Steinmaus, M. D. Miller, A. H. Smith, J. Occup. Environ. Med. 52 (2010) 1217-1224.

[28] Y. Cai, Y. Shi, P. Zhang, S. Mou, G. Jiang, Prog. Chem. 18 (2006) 1554-1564.

[29] Y. Shi, P. Zhang, Y. Wang, J. Shi, Y. Cai, S. Mou, G. Jiang, Environ. Int. 33 (2007) 955-962.

[30] L. Lu, Y. Wang, J. He, Chin. J. Geochem. 25 (2006) (Suppl. 1), 255.

[31] Z. Wang, D. Forsyth, B. P.-Y. Lau, L. Pelletier, R. Bronson, D. Gaertner, J. Agr. Food Chem. 57 (2009) 9250-9255.

[32] T. R. Tellez, C. P. Michaud, A. C. Reyes, B. C. Blount, C. B. Van Landingham, K. S. Crump, J. P. Gibbs, Thyroid 15 (2005) 963-975. 
[33] J. V. Dyke, K. Ito, T. Obitsu, Y. Hisamatsu, P. K. Dasgupta, B. C. Blount, Environ. Sci. Technol. 41 (2007) 88-92.

[34] H. Gal, N. Weisbrod, O. Dahan, Z. Ronen, R. Nativ, J. Hydrol. 378 (2009) 142-149.

[35] P. K. Dasgupta, A. B. Kirk, J. V. Dyke, S. I. Ohira, Environ. Sci. Technol. 42 (2008) 8115-8121.

[36] B. C. Blount, K. U. Alwis, R. B. Jain, B. L. Solomon, J. C. Morrow, W. A. Jackson, Environ. Sci. Technol. 44 (2010) 9564-9570.

[37] R. Srinivasan, G. Sorial, Sep. Purif. Technol 69 (2009) 7-21.

[38] R. Srinivasan, G. Sorial, E. Sahle-Demessie, Environ. Eng. Sci. 26 (2009) 1661-1671.

[39] E. Kociolek-Balawejder, L. J. Wilk, Przem. Chem. 88 (2009) 1221-1228.

[40] T. L. Theis, A. K. Zander, X. Li, J. Sene, M. A. Anderson, J. Water Supply Res. T. 51 (2002) 367-374.

[41] Y. Zhang, S. Mu, B. Deng, J. Zheng, J. Electroanal. Chem. 641 (2010) 1-6.

[42] D. B. Cordes, M. Smiglak, C. C. Hines, N. J. Bridges, M. Dilip, G. Srinivasan, A. Metlen, R. D. Rogers, Chem. Eur. J. 15 (2009) 13441-13448.

[43] X. D. Wang, W. Y. Wu, G. F. Tu, K. X. Jiang, T. Nonferr. Metal. Soc. 20 (2010) 2032-2036.

[44] L. Huang, S. Cheng, G. Chen, J. Chem. Technol. Biot. 86 (2011) 481-491.

[45] J. C. Thrash, J. I. Van Trump, K. A. Weber, E. Miller, L. A. Achenbach, J.D. Coates, Environ. Sci. Technol. 41 (2007) 1740-1746.

[46] C. S. Butler, P. Clauwaert, S. J. Green, W. Verstraete, R. Nerenberg, Environ. Sci. Technol. 44 (2010) 4685-4691.

[47] M. M. Abu-Omar, Chem. Commun. 17 (2003) 2102-2111.

[48] M. M. Abu-Omar, Comment. Inorg. Chem. 24 (2003) 15-37.

[49] K. D. Hurley, J. R. Shapley, Environ. Sci. Technol. 41 (2007) 2044-2049.

[50] Y. Zhang, K. D. Hurley, J. R. Shapley, Inorg. Chem. 50 (2011) 1534-1543.

[51] K. D. Hurley, Y. Zhang, J. R. Shapley, J. Amer. Chem. Soc. 131 (2009) 14172-14173.

[52] J. H. Xu, N. Y. Gao, Y. L. Tang, Y. Deng, M. H. Sui, J. Environ. Sci.-China 22 (2010) 1807-1813.

[53] J. H. Xu, N. Y. Gao, Y. Deng, M. H. Sui, Y. L. Tang, J. Colloid Interf. Sci. 357 (2011) 474-479.

[54] A. M. Moore, C. H. de Leon, T. M. Young, Environ. Sci. Technol. 37 (2003) 3189-3198.

[55] S. Y. Oh, D. K. Cha, P. C. Chiu, B. J. Kim, Water Sci. Technol. 54 (2006) 47-53.

[56] L. Butula, I. Butula, Croat. Chem. Acta 43 (1971) 131.

[57] G. Horányi, Catal. Today 19 (1994) 285-311.

[58] S. A. Bilmes, N. R. De Tacconi, A. J. Arvia, J. Electroanal. Chem. 143 (1983) 179-194.

[59] M. Hourani, A. Wieckowski, J. Electroanal. Chem. 244 (1988) 147-161.

[60] N. Kizhekevariam, M. J. Weaver, Surf. Sci. 277 (1992) 21-30.

[61] M. Wasberg, G. Horányi, J. Electroanal. Chem. 381 (1995) 151-158.

[62] M. Wasberg, G. Horányi, J. Electroanal. Chem. 385 (1995) 63-70.

[63] A. Ahmadi, R. W. Evans, G. Attard, J. Electroanal. Chem. 350 (1993) 279-295.

[64] A. Ahmadi, E. Bracey, R. W. Evans, G. Attard, J. Electroanal. Chem. 350 (1993) 297-316.

[65] M. Wasberg, J. Bácskai, G. Inzelt, G. Horányi, J. Electroanal. Chem. 418 (1996) 195-198.

[66] T. Pajkossy, L. A. Kibler, D. M. Kolb, J. Electroanal. Chem. 600 (2007) 113-118.

[67] G. G. Láng, N. S. Sas, M. Ujvári, G. Horányi, Electrochim. Acta, 53 (2008) 7436-7444.

[68] G. Láng, L. Péter, ACH-Models Chem. 131 (1994) 137-153.

[69] D. M. Wang, H. Y. Lin, S. Ismat Shah, C. Y. Ni, C. P. Huang, Sep. Purif. Technol 67 (2009) 127134.

[70] R. J. Magee, T. J. Cardwell in Encyclopedia of Electrochemistry of the Elements, (A. J. Bard Ed.) Marcel Dekker, New York, 1974, Vol. 2.

[71] L. Kiss, Kinetics of Electrochemical Metal Dissolution (Studies in Physical and Theoretical Chemistry, Vol. 47) Elsevier, Amsterdam, 1988.

[72] G. Láng, G.Inzelt, Electrochim. Acta 44 (1999) 2037-2051. 
[73] G. Láng, J. Bácskai, G. Inzelt, Electrochim. Acta 38 (1993) 773-780.

[74] V. Torma, G. Láng, Magy. Kém. Foly. 104 (1998) 265-276.

[75] J-B. Jorcin, M. E. Orazem, N. Pébère, B. Tribollet, Electrochim. Acta 51 (2006) 1473-1479.

[76] G. G. Láng, M. Ujvári, T. A. Rokob, G. Inzelt, Electrochim. Acta 51 (2006) 1680-1694.

[77] D. D. Macdonald, Electrochim. Acta 51 (2006) 1376-1388.

[78] M. Ujvári, G. G. Láng, Investigation of the electrochemical reduction of chlorate and perchlorate ions on rhodium, 2nd Regional Symp. on Electrochemistry South-East Europe, Belgrade, Serbia, June 6-10, 2010, Book of Abstracts, PEA-O-03.

[79] W. J. Lorenz, K. E. Heusler in Corrosion Mechanisms, (F. Mansfeld Ed.) Marcel Dekker, New York, 1987, pp 1-83.

[80] S. Y. Zhao, S. H. Chen, H. Y. Ma, D. G. Li, F. J. Kong, J. Appl. Electrochem. 32 (2002) 231-235.

[81] H. Ma, G. Li, S. Chen, S. Zhao, X. Cheng, Corr. Sci. 44 (2002) 1177-1191.

[82] F. Zucchi, M. Fonsati, G. Trabanelli, J. Appl. Electrochem. 28 (1998) 441-447.

[83] M. Ujvári, G. Láng, G. Horányi, J. Appl. Electrochem. 31 (2001) 1171-1173.

[84] M. Ujvári, G. Láng, G. Horányi, J. Appl. Electrochem. 32 (2002) 581-582.

[85] G. Láng, M. Ujvári, G. Horányi, Corr. Sci. 45 (2003) 1-5.

[86] M. Pagitsas, M. Pavlidou, D. Sazou, Electrochim. Acta 53 (2008) 4784-4795.

[87] M. A. Amin, Electrochim. Acta 54 (2009) 1857-1863.

[88] L. Li, S. H. Chen, X. G. Yang, C. Wang, W. J. Guo, J. Electroanal. Chem. 572 (2004) 41-49.

[89] J. Lei, S. Rudenja, N. Magtoto, J. A. Kelber, Thin Solid Films 497 (2006) 121 - 129.

[90] H. H. Hassan, Electrochim. Acta 51 (2006) 5966-5972.

[91] H. H. Hassan, M. A. Amin, S. Gubbala, M. K. Sunkara, Electrochim. Acta 52 (2007) 69296937.

[92] G. Láng, G. Inzelt, A. Vrabecz, G. Horányi, J. Electroanal. Chem. 582 (2005) 249-257.

[93] H. Göhr, Electrochim. Acta 11 (1966) 827-834.

[94] H. Göhr, H. Krüger, Electrochim. Acta 11 (1966) 835-847.

[95] A. M. Lecco, V. D. Canić, Glasnik Hemijskog Društva Beograd 14 (1949) 249-251.

[96] V. C. Canić, Glasnik Hemijskog Društva Beograd, 16 (1951) 13-18.

[97] G. G. Láng, A. Vrabecz, G. Horányi, Electrochem. Commun. 5 (2003) 609-612.

[98] M. Ujvári, G. Láng, G. Horányi, J. Appl. Electrochem. 32 (2002) 1403-1406.

[99] M. Y. Rusanova, P. Polaskova, M. Muzikar, W. R. Fawcett, Electrochim. Acta 51 (2006) 30973101.

[100] G. Horányi, Corr. Sci. 46 (2004) 1741-1749.

[101] G.G. Láng, M. Ujvári in Perchlorates: Production, Uses and Health Effects, (L.E. Matthews, Ed.) Nova Publishers, in press, ISBN: 978-1-61122-857-1

(C) 2011 by the authors; licensee IAPC, Zagreb, Croatia. This article is an open-access article distributed under the terms and conditions of the Creative Commons Attribution license

(http://creativecommons.org/licenses/by/3.0/) (cc) EY 